\title{
Los escenarios judiciales: la masacre vista por las víctimas y los sobrevivientes
}

$\mathrm{D}$ ías después de perpetrarse la masacre en el Alto Naya, la infantería de marina desplegó la que quizá se pueda catalogar como la primera gran acción militar contra las denominadas AUC (Autodefensas Unidas de Colombia): la operación Dignidad. Por tierra y agua se desplegaron varias fuerzas en busca del grupo de hombres que, huyendo del escenario de la masacre, seguía el curso del río Naya hacia el océano Pacífico. El golpe militar fue contundente y fueron capturados en menos de dos semanas más de sesenta personas, que fueron presentados ante los medios periodísticos como los autores materiales de la masacre.

Cuatro años después, el 21 de febrero de 2005, el juzgado primero penal del circuito especializado de Popayán condenó a 70 hombres del bloque Calima de las AUC a purgar 40 años de prisión (la máxima condena contemplada por la legislación penal colombiana) por los delitos de homicidio agravado con fines terroristas, concierto para delinquir y desplazamiento forzado. Posteriormente, el 15 de agosto de 2007, el Consejo de Estado condenó al Estado colombiano -en cabeza del Ministerio de Defensa- a indemnizar a 81 personas reconocidas como víctimas de la masacre por un monto cercano a los 6 mil millones de pesos, al demostrarse la responsabilidad por omisión 
de las Fuerzas Militares en la masacre. Por su parte, las pesquisas adelantadas por la fiscalía 21 de derechos humanos hallaron mérito para abrir investigación contra varios oficiales activos y retirados, incluyendo al general (r) Francisco José Pedraza que actuaba en la época como comandante de la Tercera Brigada del Ejército con sede en Cali, por la presunta responsabilidad en las acciones ocurridas en abril de 2001 en la región del Alto Naya. Finalmente, con la entrada en vigencia de la Ley 975 (2005) o Ley de Justicia y Paz, el grupo paramilitar del bloque Calima -incluyendo a su comandante Éver Veloza García, alias $\mathrm{HH}$ - se acogieron a la Ley de justicia transicional y ofrecieron sus versiones frente a sus actuaciones en el grupo paramilitar, incluyendo la masacre del Alto Naya, lo que eventualmente podría garantizar una rebaja significativa de la pena (un máximo de 8 años de prisión) si al final del proceso los magistrados consideran que sus declaraciones aportan a la "verdad" jurídica.

Una mirada general y quizá desprevenida sobre las actuaciones de la administración judicial en los distintos escenarios podría llevar a suponer que, en el caso que nos ocupa, se han venido garantizado los principios de justicia, verdad y reparación. No obstante, tras acompañar a algunas personas ${ }^{56}$ de las comunidades del Alto Naya que fueron reconocidas, y que se reconocen como víctimas de la masacre, es posible comprender su decepción, pues las investigaciones y los fallos judiciales no son asumidos, en algunos casos, como actos que procuren alivio material ni existencial. En ese orden de ideas, el capítulo pretende hallar los sentidos que se van construyendo y reconstruyendo en torno a la masacre como "verdad" judicial a partir de las voces de las partes involucradas, tanto en el proceso que el caso tuvo en la justicia penal ordinaria como bajo la justicia transicional. En consecuencia, se toman como unidad de análisis las sentencias que provienen

56 El acompañamiento comenzó en junio de 2011, cuando comencé a asistir a algunas diligencias relacionadas con el proceso que las fiscalías 18, 40 y 53 de Justicia y Paz, las tres con sede en la ciudad de Cali, adelantan contra 89 perpetradores del bloque Calima que se acogieron en calidad de postulados a la Ley 975 (2005). Por razones de seguridad o por solicitud de los participantes, en algunos casos los nombres de las personas serán cambiados. 
de las causas judiciales - tanto en los tribunales de la justicia ordinaria como en el marco de Justicia y Paz-, y los testimonios de algunas personas afectadas por las acciones del bloque Calima en la región del Alto Naya, quienes aún asisten a los estrados judiciales en su condición de víctimas, sobrevivientes o afectados, en un intento de superar sus angustias y sus condiciones precarias.

La argumentación procura demostrar que las confesiones de los perpetradores se configuran entre un escenario y otro sobre la base de una suerte de intereses que literalmente moldean el "libreto" confesional, pero también que las "verdades" judiciales proyectan una eficacia simbólica que resulta ilusoria para los pobladores del Alto Naya, puesto que los fallos no saldan precisamente cuentas con el pasado.

\section{Los textos judiciales como objeto de estudio}

Haber acudido a los textos judiciales para reconstruir los sentidos en torno a la masacre del Alto Naya tuvo dos dificultades. La primera está en el lenguaje que caracteriza el texto judicial, que reviste cierto grado de dificultad porque exige conocer los protocolos y las nociones de un área tan especializada del derecho (Pardo, 1992, p. 35). Por ello, no es extraño encontrar significados que literalmente resultan inaccesibles e ininteligibles para los legos, pues están construidos en un lenguaje críptico que incluso es dificultoso para los mismos operadores judiciales (Cárvoca, 2009, p. 54).

El segundo problema está en el texto mismo, pues los discursos judiciales en Colombia son transcripciones de procesos que se expresan oralmente. Esa condición obliga a trabajar con un dato editado y, por lo mismo, alterado. En esa perspectiva, teniendo en cuenta que la sentencia se aborda como un texto escrito a posteriori en un proceso judicial, el dato funciona como herramienta heurística que hace posible obtener conclusiones sobre una "realidad" a la cual no se ha asistido (Pardo, 1992, p. 26).

A pesar de estos dos problemas, el análisis de los textos judiciales parte de reconocer que en ellos hay un discurso susceptible de 
interpretación. Y, como cualquier otro discurso ${ }^{57}$, los sentidos son iguales tanto para quienes los producen como para quienes los reciben (Kerbrat-Orecchioni, 1997, p. 23). En otras palabras, los textos judiciales hay que entenderlos como artefactos de $\operatorname{poder}^{58}$ que, no obstante, son constructos sociales.

En los textos que provienen de un proceso judicial, esta perspectiva resulta relevante y significativa porque permite comprender que en cada intervención (oral o escrita) las personas que participan no pueden despojarse de concepciones y de intereses impregnados por aspectos políticos e ideológicos (Cossio, 1963, p. 94). Ahí radica la importancia de un análisis cuya materialidad es una serie de textos que - aunque transcripciones que condensan y, por lo mismo, editan lo que alguien considera fue importante- permiten rastrear las significaciones que se producen a lo largo de un proceso. Ello incluye la sentencia y el texto último donde se reconoce, ante todo, la voz del juez como el operador que tiene la responsabilidad de aplicar-valorar-interpretar ${ }^{59}$ las

57 Como lo recuerda María Laura Pardo (1992), los textos judiciales no implican un tipo especial de discurso que difiera de otros discursos, pues las estrategias y los recursos que operan en su producción son los mismos. En ese contexto, el acercamiento lingüístico será igual, y lo que varía es el acercamiento extralingüístico. De igual forma, destaca que los textos judiciales son argumentativos, dado que responden más a las convenciones de la retórica que de la lógica. En una sentencia, por ejemplo, las argumentaciones buscan ante todo demostrar y probar. De ahí la importancia en torno a lo que O’Barr (1982) denomina tácticas, entendidas como recursos a los que se apela en el lenguaje para obtener ciertos efectos en el desarrollo argumentativo de un proceso.

58 Al formar parte de la institución judicial puede resultar obvio asumir per se el texto jurídico como un texto de poder. No obstante, la obviedad queda trascendida al entender el poder como una forma de control, especialmente de la información contenida en los textos, por parte de un grupo dominante a expensas de uno dominado (Van Dijk, 1995, p. 31).

59 En este proceso, el papel del juez no es sencillo si se tiene en cuenta que los hechos no hablan por sí mismos, son siempre mudos (Calvo, 1999, p. 29). Para que esos hechos puedan ser escuchados procesalmente, el juez los reconstruye mediante un acto narrativo como ejercicio de edición y montaje. Su trabajo consiste en: 1) escuchar los argumentos de las partes y, a partir de estos, realizar una primera selección en la que se acogen y rechazan ciertos contenidos 
normas para juzgar a los imputados a través de un fallo condenatorio o absolutorio.

Un primer acercamiento, entonces, a cualquier texto jurídico permite identificar una estructura básica de tres niveles: la norma, que implica su valoración-interpretación para su aplicación por los operadores; y los efectos que se desprenden de su aplicación. Este abordaje, que solo tiene intenciones analíticas porque no son "lugares" ni "momentos" definidos, es interesante porque permite vislumbrar las instancias de producción de sentido presentes en cualquier texto jurídico (Cárvoca, 2009, pp. 163-164) Igualmente sugestiva es la tesis que concibe los textos judiciales como discursos argumentativos que presentan una orientación, un nudo y un desenlace (Labov y Waletzky, 1967) mediados por enunciados que buscan establecer criterios y conclusiones. Como textos que responden al terreno de la argumentación, una propuesta de análisis permite ahondar, con un enfoque pragmático o semántico o una combinación de ambos (Lavandera y Pardo, 1987$, p. 37$)^{60}$.

según criterios factuales, pero, sobre todo, de relevancia en relación con la configuración de la prueba; 2) el juez selecciona las pruebas, lo que implica el rechazo de las que igualmente no resulten relevantes para la causa; 3) finalmente, su trabajo se centra en organizar un relato a partir de relatos, entendiendo que buena parte del material probatorio es presentando en forma de relato. Lo cierto es que la tarea resulta compleja porque no hay ningún tipo de garantía respecto a que las elecciones-selecciones-interpretaciones del juez sean acertadas e infalibles, lo que incluye también la aplicación de una pena a la luz de una norma (Cárvoca, 2009, pp. 39-40). Comprender esta lógica de trabajo del juez, permite entender que su tarea por establecer una "verdad" jurídica a través de una sentencia es un ejercicio narrativo en el que predomina lo "verosímil" como recurso retórico que incluye lo probable y lo posible (Charaudeau y Maingueneau, 2005, p. 580).

60 En términos discursivos, es usual concebir la sentencia judicial como un texto que condensa una serie de argumentos a partir de los cuales se configura un criterio o una prueba (Ducrot, 1984). En este sentido, el enfoque de análisis es semántico en cuanto busca comprender los significados que subyacen en los argumentos expuestos en el texto. Un camino un tanto más complejo siguen Pardo (1992) y Lavandera (1987) quienes distinguen entre lo que ellas denominan argumentatividad y argumentación. Su tesis es que un texto judicial —además de la argumentación — también requiere estrategias argumentativas 
Esa lectura de sentencias judiciales — que toma herramientas metodológicas del análisis crítico del discurso-, se complementó con un ejercicio etnográfico de acompañar a tres personas de las comunidades del Alto Naya que asistieron a algunas audiencias en calidad de líderes, sobrevivientes y víctimas. El acompañamiento empieza en junio de 2011, cuando las fiscalías 18 y 40 desarrollaban las audiencias de versión libre a los antiguos integrantes del grupo paramilitar en la ciudad de Cali, y se extiende hasta octubre de 2013, cuando el Tribunal Superior de Bogotá profiere sentencia condenatoria contra Éver Veloza García, alias $\mathrm{HH}$, comandante de los bloques Calima y Bananeros de las Auc. El acompañamiento tuvo como principal propósito comprender las maneras como unas personas, que se reconocen como víctimas de un grupo armado, interpretan y viven en la cotidianeidad lo que sucede en un escenario con rituales tan especializados como los que convoca Justicia y Paz. En ese largo ejercicio, tres aspectos resultan relevantes: Primero, la dificultad que resulta desprenderse de cierta posición dominocéntrica que usualmente conduce a valoraciones miserabilistas frente a unas personas que pueden ser reducidas a simples rótulos —víctimas o sobrevivientes - naturalizados en la cotidianeidad. La relación en principio es con una víctima con la que se interactúa con el falso reconocimiento de una carencia que niega su producción simbólica, sobre todo cuando los encuentros se suscitan en escenarios judiciales, cuyos procedimientos especializados sin duda alguna representan un obstáculo; pero estos no impiden que indígenas, afrodescendientes y campesinos aprendan con rapidez las lógicas de los procedimientos de las audiencias, lo que les permite leer y valorar los rituales jurídicos en los que son protagonistas. No obstante, esa valoración dominocéntrica es recurrente en buena parte de los operadores judiciales,

a fin de que el propio texto tenga una continuidad, entendiendo que su función primordial es propiciar un espacio lingüístico en el que un emisor predica algo sobre lo que más adelante se puede volver a predicar. A esta operación, de carácter pragmático, se define como argumentatividad. La idea, grosso modo, es que un texto judicial puede irse construyendo mediante estrategias argumentativas que no necesariamente derivan en una argumentación (Lavandera, 1993). 
que consideran que las víctimas no tienen la formación especializada para comprender las dificultades de un proceso judicial ${ }^{61}$.

Segundo, el acompañamiento estuvo caracterizado por cierta tensión entre los roles que se desempeñan en el ejercicio investigativo. A la obviedad que resulta decir que los roles se reconfiguran a medida en que se alcanzan ciertos grados de familiaridad, la tensión aparece cuando ciertas realidades aparecen con tal fuerza que es muy difícil adoptar posturas que marquen distancia con personas que depositan su confianza en alguien que con el tiempo deja de ser un extraño. ¿Investigador o militante? La división entre un rol y otro puede resultar fácil de resolver en el texto que trata de plasmar con relativa claridad reflexiones sobre situaciones que siguen presentes en el pensamiento, pero en la vida cotidiana la división entre trabajo investigativo y activismo no es una cuestión sencilla de resolver, sobre todo en un contexto en el que distintas formas de violencia siguen presentes. Fueron muchas las situaciones en las que actué motivado por una solidaridad despojada de interés académico. Por eso, me declaro deudor del siempre refrescante trabajo de Veena Das (2003), Trauma and testimony: implications for political community, como texto que sirvió de ejemplo para comprender —o convencerme, tal vez- de que los trabajos investigativos también están moldeados por las necesidades de la inmediatez y el activismo (p. 295).

Finalmente, el acompañamiento produjo aprendizajes con efectos políticos en dos aspectos relevantes: por una parte, al comienzo asistí a las audiencias teniendo como referencia una incursión de un bloque paramilitar que devino en una masacre, pero el desarrollo del proceso judicial permitió un ejercicio de reflexión en el que se comprende que la masacre fue solo un evento infausto en un marco de disrupciones

61 Al respecto, señalan Grignon y Passeron (1991): “No podemos pensar en estudiar las culturas populares en su especificidad si no nos desembarazamos primero de la idea dominocéntrica de la alteridad radical de esas culturas, que conduce siempre a considerarlas como no-culturas, como 'culturas-naturalezas' [...] De igual manera, no podemos plantear así no más la cuestión de la heterogeneidad del espacio social y del espacio simbólico si no nos damos los medios (que valen lo que valen) para establecer la continuidad del espacio social y del espacio simbólico" (p. 113). 
más complejo y denso, que involucró a una amplia zona de los departamentos del Valle y del Cauca. Tejer sus recuerdos y subjetividades con una lectura geopolítica y geoeconómica — que involucra intereses de distintos actores-, es una ganancia en el agenciamiento presente y futuro. Una segunda ganancia está en reconocer y poner en marcha estrategias, especialmente comunicativas-narrativas, que permitieran agenciar sus propias versiones sobre ese pasado que no necesariamente coincide con la "verdad" judicial.

\section{Discusiones sobre la "verdad" jurídica: ¿realidades distorsionadas? ${ }^{62}$}

El 21 de febrero de 2005 — cuatro años después de que paramilitares del bloque Calima de las Autodefensas Unidas de Colombia incursionaran en la región del Alto Naya y masacraran a campesinos, indígenas y afrodescendientes-, el Juzgado Penal del Circuito Especializado de la ciudad de Popayán condenó a setenta personas a cuatrocientos ochenta meses (cuarenta años) de prisión como autores penalmente responsables de tres delitos que configuraron la masacre del Alto Naya: homicidio agravado con fines terroristas, concierto para delinquir y desplazamiento forzado. Una primera revisión del fallo de sentencia, que alcanza una extensión de 149 páginas, permite vislumbrar el esfuerzo por condensar y organizar en una estructura de diez puntos aparentemente "lógica" y "ordenada" los materiales probatorios (sobre todo declaraciones e indagatorias) y las valoraciones de los operadores judiciales (fiscales y jueces) que a la postre derivan en la resolución de acusación y en el fallo condenatorio. Como se mencionó párrafos atrás, la estructura no resulta legible ni inteligible para el lego que se acerca a la sentencia, en la que se destacan cinco apartados:

a. La presentación de los hechos en el proceso judicial y en el respectivo fallo de sentencia en los cuales se ubica la acción

62 Una versión preliminar del tema fue desarrollada en "La desilusión en los sobrevivientes de la masacre del Alto Naya en el marco de Justicia y paz" (Reyes, 2017, pp. 256-262). 
delictiva; los límites espaciales y temporales que cubre la acción; las personas involucradas en condición de acusados o afectados de la acción; las acciones institucionales emprendidas que permitieron la captura de una serie de personas, catalogadas como responsable de la acción delictiva.

b. Los antecedentes y medios probatorios, que es el apartado más extenso porque se presentan casi de forma cronológica las distintas acciones adelantadas para el esclarecimiento de la acción paramilitar, la perpetración de la masacre y la captura de sus responsable a través los testimonios ofrecidos como declaraciones de los testigos y sobrevivientes de la masacre, y de las indagatorias practicadas por los fiscales a una serie de personas que en adelante son tratados como sindicados de tres delitos que se derivaron de la incursión a la región del Naya.

c. La resolución de acusación como apartado en el que la fiscalía presenta sus valoraciones y argumentos para determinar, sobre la base de la investigación adelantada hasta ese punto, si hay literalmente mérito para acusar o no a los sindicados.

d. La audiencia pública de juzgamiento en la que se observa un trabajo de edición que solo deja lo que los jueces consideraron como más relevante en lo relativo a los largos interrogatorios con los procesados y las pruebas testimoniales presentadas por la fiscalía y por los abogados defensores.

e. La resolución de la sentencia que identifica a las personas condenadas y absueltas, los delitos que concurren a la condena y la pena que es impuesta por los jueces.

En cada una de estas etapas se construyen distintas significaciones que se desprenden de las argumentaciones presentadas. En algunos casos, esos sentidos se discuten y desvirtúan como resultado del ejercicio investigativo por la fiscalía como ente acusador, mientras otros se consolidan y legitiman para constituir la evidencia y la prueba de lo que al final es presentado como verdad. Estos últimos están soportados en unas realidades fácticas que, por lo mismo, no admiten 
discusión. Es decir, no se pone en duda que, en el caso que nos ocupa, hubo una incursión armada en la región del Alto Naya que derivó en una serie de acciones tipificadas como delitos por el código penal. Pero ¿qué ocurre cuando esa realidad factual configura "verdades" jurídicas cuyos sentidos no son compartidos por los sobrevivientes y que, diez años después, recuerdan algunos eventos de una manera distinta a lo que quedó consignado en la sentencia?

Una de las personas a las que acompañé a las diligencias judiciales fue Elvira, justificada por ser víctima de la acción paramilitar, y también por representar su comunidad. La conocí un mes antes de iniciar el acompañamiento, cuando asistí a un foro sobre el problema de la tierra en relación con el conflicto armado. Participaba como expositora invitada, y me sorprendió la claridad de su argumentación para explicar los actuales problemas que experimenta una región geoeconómicamente estratégica del Pacífico colombiano. Los primeros acompañamientos, no obstante, me permitieron observar ciertas dificultades para comprender las lógicas de las dinámicas judiciales. Por ejemplo, tenía valoraciones muy vagas sobre los marcos normativos que, en el horizonte transicional que se viene construyendo en Colombia, los reconoce como víctimas de aquello que se define como conflicto armado. En ese contexto, surgió la idea de empezar la lectura de algunos textos judiciales relacionados con la masacre de abril de 2001, que propiciara una reflexión conjunta que en algunas sesiones contó con la presencia de otros líderes y otros integrantes de las comunidades de la región.

Reunidos, entonces, en un pequeño salón de un hotel en la ciudad de Cali, comenzamos a leer el primer documento escogido: la sentencia condenatoria contra setenta hombres del bloque Calima, proferida por el Juzgado Primero Penal del Circuito Especializado de la ciudad de Popayán. El inicio de la lectura no produjo ninguna reacción, ni la emocionó ni la confrontó. Sospeché que su silencio fue producto del tecnicismo jurídico con que arranca todo texto judicial. No obstante, su actitud cambió cuando leímos la parte correspondiente a los antecedentes y medios probatorios. Su interés se despertó cuando, a través de las declaraciones de los testigos de la masacre, aparecieron los primeros relatos que describían los momentos iniciales de la incursión paramilitar y de los asesinatos. La lectura, que no fue continua, 
se volvió un ejercicio que detonó los recuerdos de Elvira. Por esa vía, comenzó a relatarme quiénes eran las personas mencionadas, cómo fueron asesinadas y cuál fue el recorrido efectuado por el grupo paramilitar. Fue inevitable ir leyendo las declaraciones consignadas en el documento judicial a medida que Elvira compartía sus recuerdos. De este modo, lentamente fuimos avanzando en un ejercicio que en principio no despertó discusión en la medida en que esta líder de 39 años compartió lo dicho en el documento. No obstante, cuando leímos el segundo párrafo del apartado que atañe a la descripción de los hechos, los recuerdos de Elvira discutieron lo escrito. El párrafo en cuestión expresa lo siguiente:

Posteriormente con fecha 27 de abril del referido año (2001), en desarrollo de la operación Dignidad, adelantada por el batallón de contra guerrilla de infantería de marina número 30, fueron capturados en el área de enfrentamiento los particulares. (Sentencia condenatoria 009, 2005, p. 2)

En otros apartados, la sentencia vuelve sobre la acción militar adelantada por la infantería de marina, que destaca la eficacia de la operación Dignidad para capturar a los responsables de la masacre. La reacción de Elvira al respecto fue de molestia, pues dijo que la operación militar no solo tardó demasiado - más de veinte días, según los comandantes de las Fuerzas Militares que sostuvieron que no fue posible ingresar a la zona en los días que siguieron a la perpetración de la masacre porque las condiciones climáticas no lo permitieron ${ }^{63}$ - y también que los militares ayudaron a escapar a algunos comandantes paramilitares que participaron en la masacre. Cuando le pedí que me explicara cómo ocurrió el asunto, me respondió que no conocía muy bien cómo se dio la ayuda pero que es un "cuento" sabido: "todos sabemos que fue así, los militares ayudaron a que se escaparan los comandantes mientras capturaban a los rasos" (notas de campo, marzo de 2012).

63 Las declaraciones fueron rendidas, entre otros, por el entonces coronel Tony Vargas, comandante del batallón Pichincha, al periódico El Tiempo (2001a). 
Durante la imputación de cargos contra los ahora postulados del bloque Calima ante Justicia y Paz, celebrada el 4 de junio de 2012 en el Tribunal Superior de Bogotá, el Fiscal 18 confirma lo que en boca de Elvira parecía ser más una sospecha que una certeza. En la diligencia, el Fiscal narra apartes de la confesión realizada por Juan Mauricio Aristizabal Ramírez, alias El Fino, quien se desempeñó como jefe de finanzas del bloque Calima. La confesión, leída por el Fiscal, indica que en la época en que fueron capturados los primeros paramilitares -finales del mes de abril-, el perpetrador contactó a un coronel de la armada de apellido Moreno para que ayudara a detener la persecución contra los hombres que huían siguiendo el curso del río Naya. Según el testimonio, el oficial respondió que no podía hacer nada, porque la orden venía directamente de la Presidencia, pero sí sugirió que se realizara otra acción militar en una zona distinta al Naya, que contribuyera a desviar la atención de la armada, y así detener la persecución. Según esta versión, a partir de la sugerencia, los paramilitares del bloque Calima planearon y ejecutaron la masacre de Yurumanguí64,

64 De acuerdo con el relato confesional, la masacre fue planeada en el municipio de Buenaventura y perpetrada por 16 paramilitares dirigidos por los comandantes Yesid Enrique Pacheco Sarmiento, alias El Cabo, y alias Félix, quien no aparece registrado como postulado en Justicia y Paz por el bloque Calima. La masacre se inició en la madrugada del domingo 29 de abril de 2001 cuando los paramilitares llegaron a la vereda El Firme, corregimiento Yurumanguí, sacaron a los pobladores de sus ranchos, los reunieron en la playa y los hicieron tender en el piso bocabajo. Tras seleccionar a algunos pobladores para asesinarlos bajo la acusación de ser auxiliadores de las autodefensas (los paramilitares se presentaron como integrantes del Frente 30 de las Farc-EP), alias El Cabo violó a una mujer mientras la amenazaba con un arma. Posteriormente, mandó conseguir machetes para no efectuar disparos, pero como no encontraron ninguno utilizó un hacha con la que decapitó y descuartizó a dos personas, luego cedió el arma a sus subordinados para que continuaran la tarea. El acto provocó que varias personas que estaban tendidas en la playa salieran corriendo, buscando refugiarse en la selva. Los paramilitares, entonces, dispararon indiscriminadamente. En su huida del lugar saquearon y quemaron algunas viviendas. También pintaron mensajes alusivos a las Farc-EP, buscado inculpar al grupo insurgente de la acción. En total, fueron asesinadas siete personas, además del desplazamiento de las comunidades de la zona, dedicadas a la agricultura y la pesca tradicional. 
que contribuyó a disminuir la presión que las Fuerzas Militares tenían sobre un grupo de 24 hombres que estaban atascados en la zona de Puerto Merizalde (Valle del Cauca), lo que permitió su huida. Mientras la magistrada solicita a la Fiscalía que aclare la identidad del mencionado coronel Moreno, Elvira pronuncia en voz baja: "vaya una a saber si en las mismas lanchas del Ejército salieron los desgraciados" ${ }^{65}$.

Esa primera discusión que Elvira planteó respecto a uno de los tantos sentidos que se van registrando en la sentencia judicial, trasciende la inquietud personal respecto a un caso concreto cuando sus comentarios indican un problema estructural del sistema penal colombiano: el testimonio como uno de los principales recursos probato$\operatorname{rios}^{66}$. En este sentido, cabe preguntar: ¿cuáles son las particularidades que adquieren las voces en escenarios tan especializados como los que registra el sistema judicial?

65 En las audiencias de Justicia y Paz, por lo menos tres desmovilizados, entre ellos Heyber González Muñoz y José Antonio Morales Galindo, confesaron que durante la captura por la infantería de marina fueron increpados por los militares porque, según los uniformados, presuntamente se dio la orden de darles a los paramilitares un plazo de quince días para que pudieran salir de la región tras la incursión. Por ejemplo, Luis Fernando Martínez Ramos, alias El enano, afirmó que cuando fue capturado le dijeron: “¿Qué les pasó? Si ustedes tenían 15 días para salir... Ya no los podemos soltar porque nos pusieron demanda”.

66 Dos comentarios al respecto: primero, discutir el testimonio que surge de un proceso judicial no significa desconocer su relevancia en el plano jurídico, donde el relato es material probatorio, y en el plano social, donde el relato trasciende la idea de un recurso factual y meramente informativo (Pollak, 2006, p. 55); segundo, si bien las pruebas periciales presentadas por las partes involucradas son un recurso que garantiza el sistema penal acusatorio en Colombia, este encierra una dificultad manifiesta porque son precisamente las partes las que deben costear los procedimientos. En casos como el que nos ocupa, la representación de las víctimas está en manos de la Fiscalía General de la Nación, que practica los procedimientos que están a su alcance. Si las víctimas quisieran tener una participación directa, tendrían que constituirse en parte civil de la causa judicial y pagar los procedimientos. Pero se trata de comunidades que no tienen los recursos económicos para hacerlo. De ahí que el testimonio siga siendo el recurso probatorio que prevalece. 
Michael Pollak (2006) ofrece reflexiones que contribuyen a comprender el asunto al preguntarse sobre qué hace posible el testimonio, puesto que también es posible reconocer que hay un "silencio deliberado" por aquellos que hacen un esfuerzo para no evocar públicamente como un mecanismo de superación del pasado ${ }^{67}$. A partir de distintos corpus de testimonios, Pollak identifica tres formas de obtención de este: las declaraciones judiciales, los escritos autobiográficos y las historias de vida. Estas tres formas son el resultado del encuentro entre los que están dispuestos a hablar y la disposición de los que están interesados en escuchar y conocer, estableciendo los "límites de lo que es efectivamente decible” (p. 56). Esto es interesante, especialmente para el actual contexto político y social colombiano, porque, como recalca Pollak, el hablar públicamente sobre el pasado no es una decisión que dependa exclusivamente de la voluntad o la capacidad de una persona para reconstruir la experiencia pasada; todo testimonio está anclado a las condiciones sociales que hacen que la experiencia sea o no comunicable, condiciones que mutan con el tiempo y cambian de un lugar a otro. Habría que agregar, en el caso colombiano, las garantías, en todo el sentido de la palabra, que tienen las víctimas y los perpetradores para ofrecer sus testimonios en un contexto en el que prevalece la violencia ${ }^{68}$.

67 Jelin trae a colación el caso de Jorge Semprún (1995), quien, después de cincuenta años de silencio, incorpora en La escritura de la vida su encuentro con el agonizante Halbwachs en el campo de concentración de Buchenwald.

68 De acuerdo con los informes de las organizaciones sociales, desde la entrada en vigencia de la Ley de Justicia y Paz la persecución, el hostigamiento y el asesinato selectivo han sido las estrategias para acallar a personas en condición de desplazamiento y líderes comunitarios que representan a las víctimas. Aunque no se tiene una cifra precisa, los líderes asesinados suman más de sesenta. Pero esa misma amenaza también envuelve a los perpetradores que sienten la presión cuando en sus confesiones vinculan a miembros de las Fuerzas Militares, dirigentes políticos, terratenientes, ganaderos o empresarios. La preocupación sobre el particular fue expresada por uno de los principales comandantes de las AUC, Salvatore Mancuso, en junio de 2012. Ante las preguntas formuladas por periodistas de la cadena radial Caracol respecto a los vínculos del paramilitarismo con el hermano del expresidente Álvaro 
En este sentido, la declaración judicial representa un tipo extremo de testimonio por la forma como es solicitada y por la "generalización de la experiencia individual", tornándolo "impersonal" y "constrictivo" (Pollak, 2006, p. 62). Esto es producto de lo restringido que resulta el testimonio, puesto que se limita a aspectos puntuales del acontecimiento que exigen respuestas precisas a interrogantes puntuales. En ese contexto, la persona en su calidad de testigo desaparece detrás de los hechos. De igual forma, su interlocutor es un profesional o un operador judicial que en representación de la institución jurídica tiene como objetivo establecer o restituir la "verdad", lo que implica que se eliminen todos los elementos que están por fuera del tema. Puntualiza Pollak (2006):

Teniendo que dar a la defensa la posibilidad de introducir todos los elementos de prueba y de justificar su decisión en función de todos los testimonios ofrecidos en las deliberaciones, el juez crea por así decir un material que debería permitir (a él y posteriormente a los historiadores) ofrecer una visión "justa" ("verdadera”) de la realidad, mediante el contraste de testimonios sucesivos. (p. 62)

Para los líderes de la región del Naya que continúan asistiendo a las audiencias de Justicia y Paz, la limitación se vuelve aún más problemática cuando se transita de la etapa de instrucción al juicio, pues sus actuaciones se constriñen a un punto que llegan a considerar que su presencia en realidad no es relevante, lo cual provoca frustración por los esfuerzos que tienen que realizar para presenciar una audiencia. A manera de ejemplo, para que Elvira pudiera asistir a una audiencia implicó salir de la región con tres días de antelación en un recorrido que incluye una caminata de más de siete horas por el difícil camino que de la parte alta de la cordillera conduce al municipio de Timba. De ahí toma transporte para que, en un promedio de dos horas y media, pueda llegar hasta el municipio de Santander de Quilichao.

Uribe Vélez, Santiago Uribe, el perpetrador respondía: “sobre ese asunto prefiero guardar silencio... porque cada vez que hablo le quitan la seguridad a mi familia”. 
Se agregan 45 minutos más de recorrido hasta la ciudad de Cali. Si la audiencia se realiza en esa ciudad, los desplazamientos son más cómodos porque se retorna a Santander de Quilichao, donde usualmente hay familiares o amigos que ofrecen alojamiento y alimentación, pero si la audiencia es en Bogotá, el viaje se prolonga ocho horas más por vía terrestre, pues muchas veces carece de recursos para viajar en avión. En Bogotá, además, deben asumir los costos de hospedaje (usualmente modestos) alimentación y transporte en la ciudad cuando no pueden recurrir a algún conocido o a una organización. Cabe agregar que no reciben ningún tipo de apoyo económico en gastos que, dependiendo del lugar donde se celebra la audiencia, oscilan entre los 300 mil y un millón de pesos, es decir, 150 a 500 dólares. De ahí la desazón que experimenta Elvira cuando su rol en las audiencias de Justicia y Paz se restringe a escuchar lo que se dice, en una dinámica que la líder siente como "aburrida" ". La sensación se transforma cuando el magistrado rompe el protocolo y permite que los líderes puedan hablar sobre lo que "piensan" o "sienten" respecto a lo que se ha dicho en la jornada.

\section{¿Cuántos fueron los muertos de la masacre?}

Las inquietudes de Elvira respecto a lo que se consigna en la sentencia vuelven a cuestionar el testimonio como recurso sustancial en la etapa de instrucción. Las críticas ahora se enfocan en el tópico que más discusión sigue suscitando: el número de personas asesinadas. Desde un comienzo, los habitantes de la región, y las organizaciones sociales

69 La expresión podría calificarse como prosaica si no fuera porque es una valoración que ha sido objeto de reflexión por algunos juristas. Especialmente destaco el apartado que dedica Mark J. Osiel (2000), en torno a los juicios enmarcados en el derecho liberal donde la sobriedad prevale sobre el dramatismo, perdiendo así la fuerza simbólica que el juicio posee como ritual. Además de un desarrollo cargado de lo que muchos oyentes consideran "minucias irrelevantes", la neutralidad del proceso despoja a los acusados de su aura de “villanos" (p. 93). En el proceso contra el bloque Calima, y en otros procesos contra paramilitares postulados a la Ley 975 (2005), el asunto se torna extremo cuando los perpetradores ni siquiera están presenten en la sala, y su presencia está mediada por la pantalla de un televisión. 
a través de los comunicados, refirieron la muerte de más de cuarenta personas en la incursión de abril de 2001. La versión, incluso, fue recogida por los medios periodísticos que, en los días siguientes a la perpetración de la masacre, presentaron las declaraciones de las personas que salían huyendo de la región, advirtiendo que varios cadáveres de las personas asesinadas por los paramilitares se encontraban a la intemperie a lo largo del camino que conduce al Alto Naya, mientras otros fueron arrojados a los profundos abismos de la zona ${ }^{70}$. No obstante, la verdad judicial que aparece en los textos jurídicos reconoce otras realidades que no son aceptadas por los habitantes del Naya. En el caso de la sentencia de justicia ordinaria de febrero de 2005, si bien recoge la versión de los cuerpos arrojados por los abismos y se inicia la causa con el reconocimiento de 29 personas asesinadas, la acusación de la fiscalía y el fallo condenatorio se basan en un total de 19 personas asesinadas. Por su parte, Justicia y Paz adelanta la causa sobre el reconocimiento de 24 asesinatos, en un ejercicio que retoma las investigaciones periciales adelantadas por la justicia ordinaria. Conversando con Elvira sobre el particular, entiendo que su molestia trasciende el tema del número de personas asesinadas que debe ser reconocido "oficialmente" cuando se evoque la masacre ${ }^{71}$, pasa, nuevamente, por las lógicas de las tecnologías que caracterizan al proceso judicial, donde las

70 Las versiones fueron recogidas por el periódico El Tiempo: “Confirman 29 muertos en el Alto Naya”, (El Tiempo, 2001b); "Semana de horror en el Naya”, (El Tiempo, 2001c); “Terror paramilitar en el Naya” (El Tiempo, 2001d).

71 El sentimiento de Elvira tiene sentido en un país cuya violencia reciente ha tenido en la masacre su expresión más lamentable. Para esta comunera de origen nasa, lo ocurrido en el Naya es doloroso más allá de si los muertos fueron dos o cincuenta. Pero el tema de las cifras se vuelve trascendente en cuanto producto de unos relatos jurídicos y mediáticos que califican la "gravedad" del evento en proporción al número de personas muertas. Incluso, el tema de las cifras, temporalidades y espacialidades ha sido un asunto que ha motivado discusiones en algunos centros de investigación, incluyendo el Centro de Memoria Histórica, dado que es una modalidad de violencia no reconocida por el código penal colombiano. Esas discusiones han permitido establecer que se habla de masacre cuando se produce el homicidio de cuatro o más personas en estado de indefensión, en iguales circunstancias de modo, tiempo y lugar. Ahora, 
voces de los que vivieron la masacre y declararon en calidad de testigos es puesta en duda.

El acto de testimoniar —siguiendo a Paul Ricœur (2008)— está caracterizado por una serie de rasgos, a saber (pp. 211-213):

a. La declaración de una realidad factual en el acontecimiento relatado, ligado a su "autenticidad" y su "fiabilidad". Esa facticidad en torno a lo que se atestigua marca la distinción entre realidad y ficción.

b. La confirmación de una realidad está aparejada con la designación de la persona que atestigua, en un triple deíctico (primera persona del singular, tiempo pasado del verbo y la mención del "allí" respecto al "aquí”) del cual se deriva la fórmula "yo estaba allí”.

c. La autodesignación se enmarca en un intercambio de una situación de diálogo. El testigo habla sobre una realidad en la que se da la posición de un tercero respecto a los otros protagonistas de la acción. Esa condición implica lo que Ricœur considera es una situación fiduciaria: el testigo pide ser creído. En otras palabras y en la misma perspectiva en lo plantea M. Pollak (2006), el testimonio no solo requiere de un "otro" que esté dispuesto a escuchar, sino también que en esa escucha sea creído lo que dice.

d. Lo anterior no implica que la sospecha desaparezca, y esa posibilidad de sospechar conforma un escenario de controversia que enfrenta a varios testimonios y a varios testigos. En algunos casos, ese enfrentamiento estará en función de ratificar lo que se dice o de controvertirlo.

e. La anterior situación incorpora, según Ricœur, una dimensión suplementaria de orden moral que contribuye a reforzar la 
credibilidad del testimonio: la posibilidad del testigo de reiterar su testimonio.

f. Esa disposición a ratificar lo que se testimonió ante cualquiera que lo solicite, hace del testimonio un elemento que proporciona seguridad, fiabilidad y garantía, convirtiendo el testimonio en una institución en cuanto su estabilidad es prenda de garantía para un vínculo social que descansa en la confianza en la palabra del otro. Como lo remarca Ricœur (2008), el intercambio está abierto tanto para el dissensus como para el consensus en una dinámica que fortalece el vínculo social (p. 214).

Matizados tanto el caso que se analiza como el contexto que fija el sistema judicial donde este se desenvuelve, los anteriores factores permiten reflexionar sobre un aspecto que, a mi modo de ver, es problematizado por algunos sobrevivientes de la masacre, teniendo como excusa el número de personas asesinadas: la fiabilidad, veracidad y credibilidad que se otorga a sus voces.

En esta oportunidad, la lectura es colectiva e incluye a varios líderes de la región. La lectura se concentra en las sentencias de justicia ordinaria y en las confesiones de los paramilitares según la Ley de Justicia y Paz (Ley 975, 2005). Sus inquietudes y discusiones parten de reconocer que, por muy importantes y verídicas que puedan resultar sus versiones frente a temas como el lanzamiento de personas muertas por los abismos, no se puede juzgar y condenar a nadie cuando materialmente no existe un cuerpo como principal evidencia. Su molestia, entonces, radica en lo que ellos consideran fue una ausencia de voluntad de la fiscalía para practicar pruebas que pudieran corroborar las versiones de los testigos. La versión oficial de la fiscalía es que las condiciones

Naya es una gran evento que se inicia despuntando el año 2000 y se extiende a lo largo de cuatro años. Ese gran evento, omnipresente en el relato de las personas con las que hablé, está compuesto por distintos eventos que incluyen pequeñas masacres, desapariciones forzadas, asesinatos selectivos, desplazamiento forzado; la mayoría de estos eventos fueron invisibles. Por lo mismo, los testimonios buscan encuadrar de manera estratégica muchos episodios vividos con la incursión de abril de 2001. 
geográficas y de seguridad de la zona fueron una limitación, argumento probable porque efectivamente los accesos son difíciles, con abismos cuyo fondo supera los 200 metros, y las condiciones de seguridad son precarias en una zona dominada militarmente por las Farc-EP. Un argumento complementario, no obstante, se puede encontrar en un documento oficial de la fiscalía que establece que

la actividad probatoria debe estar orientada hacia la construcción de argumentos que permitan inferir con alta probabilidad (más allá de toda duda razonable) que ciertos hechos ocurrieron de determinada manera, para adecuarlos luego a una norma y establecer así las consecuencias que de ello se derivan. (Bedoya, 2008, p. 30)

Respecto a la masacre del Alto Naya, un funcionario de la fiscalía me comentó que el tema de las personas asesinadas terminaba siendo un elemento de segundo orden porque el material probatorio recabado (los cuerpos como evidencia fáctica de la masacre), aunado a las declaraciones de los testigos permitieron formular una acusación contra los paramilitares capturados. En otras palabras, 19 cadáveres reconocidos fueron evidencia probatoria suficiente para construir la base de una acusación por asesinato múltiple. Con esa evidencia probatoria el esfuerzo de la fiscalía, según el funcionario, estuvo en construir los argumentos que pudieran demostrar la sevicia de los paramilitares en su accionar, para formular una acusación de asesinato con fines terroristas, para lo cual la versión de los cuerpos lanzados por los abismos resultó fundamental puesto que demostró la intención de los perpetradores de no dejar huellas ${ }^{72}$. El problema es

72 De hecho, los fiscales 17, 18 y 53 de Justicia y Paz lograron establecer cinco prácticas para desaparecer cuerpos, tras analizar 133 casos perpetrados por los bloques Calima y Bananeros, comandados por Veloza García: 1) enterrar los cuerpos en fosas comunes ubicadas en zonas rurales; 2) desmembrar los cuerpos para luego enterrarlos en fosas comunes; 3) arrojar los cuerpos a los ríos; 4) lanzar los cuerpos por los abismos; 5) incinerar los cuerpos. En audiencia celebrada el 27 de octubre de 2013, despacho 17 de Justicia y Paz, Veloza García confesó que la estrategia fue implementada en complicidad con miembros de las fuerzas militares y comandantes de Policía de los municipios. En 
que ese tipo de explicaciones son excluidas de la redacción final de la sentencia, y lo que queda como "verdad" judicial es que los paramilitares del bloque Calima fueron condenados por el asesinato de 19 personas cuyos cadáveres fácticamente fueron reconocidos en el desarrollo de la causa ${ }^{73}$.

Como ya se planteó, esa sensación crece cuando la masacre es abordada en el escenario de Justicia y Paz, basada en los testimonios que ofrecen los perpetradores (Romero, 2012, p. 10); las voces de las personas que se consideran víctimas, sobrevivientes o afectados quedan literalmente relegadas a un segundo plano, en la mayoría de las ocasiones para legitimar la eficacia de las diligencias respecto al establecimiento de unas "verdades" judiciales ${ }^{74}$. Esa posición figurativa es

las fosas comunes, la modalidad más empleada, señala el perpetrador: "hay gran parte de responsabilidad de la Fuerza Pública, que son los indirectos responsables de esa modalidad de las fosas... porque empiezan a solicitarnos que por favor no dejemos muertos en los municipios, que no dejemos los muertos tirados, sino que los desaparezcamos y que los enterremos para que ese índice no se suba tanto... ahí es donde comienza a operar y a implementarse ese modo de fosas comunes, porque ellos muchas veces permitían cometer el hecho, pero con el compromiso de no dejarlos por ahí".

73 Como lo señalan Jonh Conley y William O’Barr (1991): "La ley selecciona entre voces, silenciando algunas y transformando otras para ajustarse a las categorías y convenciones legales. La mayoría de las voces son silenciadas; aquellas que sobreviven lo hacen en una forma escasamente reconocible" (citados en Castillejo, 2009, p. 4).

74 La eficacia de la norma, implicada en la función social del derecho, se observa en los resultados instrumentales o simbólicos que tiene la Ley 975 (2005); es decir, entre la conducta prevista y el resultado obtenido en la aplicación de la ley - eficacia instrumental-, y las representaciones sociales que se desprenden del discurso para producir efectos que trascienden el ámbito jurídico - eficacia simbólica-. En las audiencias de Justicia y Paz contra el bloque Calima, se destaca, según los operadores judiciales, la eficacia de la norma (tanto instrumental como simbólica) al permitir que se revelen, a través del modelo confesional de las versiones libres, una serie de eventos delictivos perpetrados en la región del Naya. Esa eficacia queda comprobada cuando los perpetradores aceptan los cargos imputados por la Fiscalía, procedimiento legal adelantado en presencia de las víctimas, sobrevivientes y afectados de la masacre. No obstante, esa lectura es discutida por los sectores (organizaciones sociales, organizaciones de base y organizaciones de derechos humanos, 
producto de la naturaleza que subyace a la Ley 975 (2005) que buscó la desmovilización de las estructuras paramilitares a cambio de ofrecer, a través de sus confesiones, "verdad". Ello implica que los paramilitares que se acogen a la ley implícitamente parten de la base de aceptar su responsabilidad en la perpetración de una serie de delitos. Pero esa aceptación no significa que las confesiones estén despojadas de intereses de diversa índole que moldean la declaración.

Las limitaciones que experimentan algunas personas afectadas por la masacre del Naya para ofrecer sus testimonios en las diligencias de Justicia y Paz tiene un aspecto límite que, incluso, propicia una situación liminar: su propio reconocimiento como víctimas en el marco transicional. De acuerdo con el artículo 5 de la ley, las personas que se consideren afectadas por las acciones de un miembro que pertenezca a un grupo armado organizado al margen de la ley serán consideradas victimas, independientemente de que se identifique, aprehenda, procese o condene al autor de la conducta punible. De igual forma, la norma establece un protocolo para que la persona que se autorreconozca como víctima pueda acreditarse ante la Fiscalía General de la Nación. Esta acreditación no es un reconocimiento, pues es el perpetrador en calidad de imputado quien legitima esa condición cuando reconoce que efectivamente esa persona fue víctima de sus acciones. En caso de que el perpetrador niegue a la persona o a la acción que se le imputa, será la investigación que adelante la Fiscalía la que determine su responsabilidad, pero antes de ello la víctima no es reconocida como tal ${ }^{75}$. El problema es que la "víctima" experimenta una situación

especialmente) que sostienen que la norma no ha logrado garantizar los principios de verdad, justicia, reparación y no repetición, teniendo como fundamento las propias cifras oficiales, lo que demostraría la ineficacia (instrumental y simbólica) de la ley.

75 Como se mencionó, las limitaciones y los vacíos de la Ley de Justicia y Paz respecto a las víctimas parten de su naturaleza, pero el asunto se agrava cuando la propia administración de justicia reconoce que no cuenta con la infraestructura para adelantar con eficacia y diligencia la cantidad de procesos que se llevan a cabo en el marco de Justicia y Paz, lo cual se traduce en resultados precarios respecto al reconocimiento de víctimas, así como el juzgamiento y condena de los perpetradores que se acogen a la ley. De acuerdo con datos 
paradójica porque, mientras la investigación judicial verifica, es y no es víctima. En otras palabras, ambigüedad y paradoja es lo que caracteriza su posición en el escenario de Justicia y $\mathrm{Paz}^{76}$.

Es el caso de Rosa, campesina que migró a la región del Naya cuando despuntaba la adolescencia. Su esposo fue desaparecido la noche del 4 de octubre de 2000 por los paramilitares que salían a patrullar las veredas de la región, teniendo como epicentro el municipio de Timba, Valle del Cauca. Lo que ella sabe de lo ocurrido con su esposo lo conoce a través de rumores que le permiten reconstruir un itinerario que incluye una golpiza, un disparo en una pierna y un cuerpo descuartizado y arrojado a las aguas del río Cauca. Aunque en su momento tuvo la ilusión de que todo fuera una mentira, la confirmación del asesinato de su esposo se logró a través de un amigo que ingresó a las filas de los paramilitares. No obstante, lo buscó por varios días entre las veredas. Al final buscó entre las aguas del río Cauca; halló muchos cuerpos, pero nunca encontró el cadáver del padre de su primer hijo. No logró que algún cadáver fuera el suyo. Rosa está acreditada como víctima ante la Fiscalía, pero no ha sido reconocida oficialmente

oficiales de la Fiscalía, hasta el 1 de diciembre de 2012 solo se habían proferido 14 sentencias condenatorias. El cuello de botella es que no hay suficiente personal (tan solo 59 fiscales) para investigar la cantidad de delitos confesados por los perpetradores desmovilizados. El informe de la Fiscalía del 1 de enero de 2013 señala que entre 2005 y 1 de diciembre de 2012 los perpetradores confesaron 39546 crímenes que involucran a 51906 víctimas, entre los cuales se encuentran 25757 homicidios, 1046 masacres, 11132 personas desplazadas, 1916 secuestros, 1618 reclutamientos ilícitos, 773 torturas y 96 casos de violencia sexual. Las confesiones llevaron a que los fiscales exhumaran 3929 fosas y hallaran 4809 cadáveres. Los datos se pueden verificar en la página de la Fiscalía General de la Nación (JyP, 2012).

76 La afirmación nuevamente está soportada en cifras: de acuerdo con el Centro de Proyectos para el Desarrollo (Cendex) de la Pontificia Universidad Javeriana, en cinco años de vigencia de la ley (2005 a 2010) se acreditaron como víctimas 314133 personas ante la Fiscalía General de la Nación, pero solo 36 mil personas $(11 \%)$ fueron reconocidas como tales, en un proceso que parte del reconocimiento por el perpetrador de los hechos victimizantes y de las personas víctimas de sus acciones. En ese contexto, en un corte de cinco años, solo 1194 personas fueron reparadas en el marco de Justicia y Paz, que equivale al $0.04 \%$, en su condición de víctimas del conflicto interno armado (Eslava, 2012). 
porque no existe una declaración de los hombres del bloque Calima en la que se acepte o se corrobore que la desaparición y posterior muerte de su esposo ocurrió. Ella sabe que, frente a la Fiscalía, ello no significa que se desconozca la veracidad de su testimonio ni, mucho menos, la desaparición de su compañero; pero tendrá que esperar a que el ente investigador demuestre la responsabilidad del bloque Calima en relación con la desaparición de su marido para que pueda obtener "oficialmente" un reconocimiento como víctima.

El testimonio de Rosa merece dos comentarios en la medida en que recoge el sentir de muchas personas con las que conversé. El arribo del bloque Calima a la región del sur del Valle y norte del Cauca implicó el despliegue de una doble estrategia: por una parte, el reclutamiento voluntario de jóvenes campesinos de la zona (los testimonios de los perpetradores en las audiencias coinciden en señalar que se les ofrecía en promedio 300 mil pesos, unos 150 dólares, por "trabajar" con los paramilitares); por otra, infiltración de los paramilitares en las actividades cotidianas de las comunidades, especialmente en las actividades relacionadas con la siembre y la recolección de hoja de coca. De ahí que los testimonios no expresen sorpresa cuando señalan que muchos labriegos y raspachines luego aparecían vestidos con prendas militares. No obstante, los testimonios también son claros en no considerar este escenario como un caso de "vecindad", tal como lo desarrolla Kimberly Theidon (2006) $)^{77}$. La permanencia de los "infiltrados" fue siempre efímera, aunque, según los testimonios, ineficaz de cara al

77 Sobre el particular, cabe destacar especialmente el estudio en torno a los "encapuchados", sobre la que se toma esta figura como símbolo en los relatos de las y los campesinos sobrevivientes a los años de guerra que enfrentó al Estado peruano con el grupo insurgente Sendero Luminoso. El interés de Theidon (2006) está en comprender lo que hay detrás de esa máscara que representa la capucha, donde los "encapuchados", además, eran usualmente vecinos y familiares de la población víctima de la violencia. Explica Theidon que el encapucharse se entiende como un mecanismo que le permite al perpetrador fijar distancia frente a la víctima, delegando en su "doble" la acción que ejecuta. El interés de esta figura está en que el "encapuchado" también es una figura presente en muchas acciones armadas en el conflicto armado colombiano, atribuido especialmente a los grupos paramilitares. De igual forma, Theidon explora los significados sociales y psicológicos de la figura para 
argumento que siempre esgrimieron los perpetradores para justificar los asesinatos y las desapariciones:

Ellos siempre han dicho que lo que hicieron fue contra personas que eran auxiliadores de la guerrilla, lo cual es mentira porque muchas de las personas asesinadas antes, durante y después de la incursión de abril (2001) era gente de la región que nada tenían que ver ni con las Farc ni con el ELN. Valiente inteligencia la que hicieron. (Anónimo, notas de campo, marzo de 2012)

Un segundo aspecto está en la desaparición literal del cuerpo como acto simbólico que despliega ese lenguaje de terror (Taussig, 1984; Robin, 2009; Korstanje, 2010) que, al estar precedido por el descuartizamiento como forma de tortura, provoca pánico colectivo. En otras palabras, a través de los testimonios es claro que los pobladores del Naya comprendieron una estrategia político-militar en la que se busca desaparecer para no dejar huella pero, al mismo tiempo, visibilizar para amedrentar.

Recapitulando: la sentencia que en la actualidad tiene tras las rejas a poco más de sesenta paramilitares que perpetraron la masacre estuvo soportada sobre el pleno reconocimiento de 19 personas asesinadas, evidencia más que suficiente para acusar y juzgar a los imputados bajo el cargo de asesinato con fines terroristas; aunque la fiscalía es consciente de que el número de personas fue mayor, no tienen la capacidad para adelantar las investigaciones en una región agreste y de difícil acceso por sus accidentes geográficos y por las condiciones de seguridad porque es controlada militarmente por las Farc-EP ${ }^{78}$. El

analizar, entre otros aspectos, los significados que se aceptan cuando las y los campesinos enfrentan a los perpetradores.

78 La región del Alto Naya es controlada militarmente por las Farc-EP. Por lo cual, para el ingreso de cualquier funcionario del Estado, las comunidades deben tramitar los respectivos permisos. En el caso de los funcionarios de la Fiscalía, ese permiso ha sido siempre negado, sin que se ofrezcan mayores explicaciones. Sobre esa base, los fiscales prefieren reconocer su incapacidad para adelantar acciones cuando las condiciones de seguridad no están dadas, pues son las comunidades las que pueden ofrecer garantías a través de su agenciamiento con el grupo insurgente. 
texto de la sentencia, no obstante, omite esta justificación que es probable e implícitamente establece como "verdad" judicial que los masacrados en la incursión paramilitar de abril de 2001 en la región del Naya fueron veinte personas. Las versiones que once años después aún insisten en que los asesinados fueron más de cien, muchos de ellos lanzados por los peñascos, han tomado la forma de un rumor que con el paso de los años las irá acercando a la ficción ${ }^{79}$. Y eso es lo que molesta a muchos sobrevivientes de la masacre, pues sienten que su versión no tiene peso suficiente en unos escenarios judiciales cuyos procedimientos responden a una tecnología que construye unas "realidades" que, a pesar de lo discutibles o polémicas que puedan resultar, tienen la virtud de gozar de un aura de legitimidad. Estos son procedimientos que se proponen garantizar los derechos a todos los actores involucrados en el proceso, se adopta la decisión difícil de creer aunque se puedan comprender los argumentos "lógicos" que la justifican.

Esto ocurre cuando en la lectura de la sentencia Elvira y otros líderes se percatan de una decisión hasta ese momento desconocida: la prescripción de los delitos de concierto para delinquir agravado por la finalidad y desplazamiento forzado por la sala de casación de la Corte Suprema de Justicia, fechada el 22 de abril de 2009. Los argumentos para tomar la decisión — ligados al vencimiento del tiempo que transcurre entre la resolución de acusación y la ejecución de la pena- no resultan relevantes para el análisis, pues, como lo sostienen los operadores

79 Esta apreciación es producto de lo que perciben algunos representantes de las víctimas. Incluso, uno de los líderes de la Asociación de Cabildos del Norte del Cauca (Acin), que acompañó a las víctimas y sobrevivientes de la región del Naya en las audiencias celebradas en la ciudad de Cali, no dudó en establecer un parangón con uno de los pasajes más dramáticos de la novela Cien años de soledad (García-Márquez, 1967): la masacre de los trabajadores y sindicalistas que protestaban contra la compañía bananera. En ese pasaje, José Arcadio Segundo es el único sobreviviente de la acción, pero cuando narra lo acontecido nadie le cree: “'Seguro que fue un sueño', insistían los oficiales. 'En Macondo no ha pasado nada, ni está pasando ni pasará nunca. Este es un pueblo feliz'. Así consumaron el exterminio de los jefes sindicales". No obstante, el personaje insiste hasta el final en su vida: "Eran más de tres mil... Ahora estoy seguro que eran todos los que estaban en la estación". La alusión a la novela llamó la atención de varios asistentes, lo que motivó a una lectura colectiva. 
judiciales, la decisión estuvo "adoptada en derecho". La decisión, no obstante, sí resulta ilustrativa para aceptar, por un lado, que en esas "lógicas" que subyacen a los procedimientos judiciales, los defensores apelan a todas sus estrategias jurídicas para que sus defendidos obtengan los mejores beneficios que concede la ley. Por otro lado, que las decisiones judiciales tienen efectos que "configuran realidades" que, en este caso, se tradujeron en la prescripción de la acción penal y en la cesación del procedimiento adelantado contra los condenados, que redujo su pena de 480 a 456 meses de prisión. La decisión judicial no transforma sustancialmente la situación de los paramilitares condenados (la rebaja efectiva es de dos años de presidio), pero sí ofrece la excusa para que los líderes pongan en discusión otro lunar que sigue teniendo la justicia en el caso del Naya, relacionado con la responsabilidad de algunos integrantes de las fuerzas militares en la masacre, pues ha sido evidente que los abogados que defienden al general retirado Francisco José Pedraza, comandante en la época de la Tercera Brigada del Ejército, y el coronel retirado Tony Alberto Vargas Petecua, han desplegado todas sus argucias para dilatar las investigaciones judiciales, buscando el vencimiento de términos.

\section{Tiempos y espacios: otra mirada sobre la memoria}

La rigurosidad técnica de los operadores judiciales trae consigo la minimización y la oclusión de los recuerdos que, consignados en las declaraciones al rendir su versión como testigos, no coinciden con la prueba pericial. Ese recuerdo, que los operadores judiciales no dudan en catalogar como "fantasioso", "fatuo" o "exagerado", es desestimado y, por tanto, carente de validez en un ejercicio en el que la sospecha siempre desempeña un papel preponderante, al punto que eventualmente puede configurarse el delito de falso testimonio si la administración de justicia llega a comprobar que la versión ofrecida buscó deliberada e intencionalmente tergiversar la "realidad" ${ }^{80}$. Por ello, para los in-

80 No debe confundirse el argumento con el derecho que en la legislación colombiana tiene toda persona a no declarar contra sí mismo, contra su cónyuge, 
vestigadores judiciales las primeras declaraciones son esenciales para esclarecer lo acontecido, porque los recuerdos están "frescos” (notas de campo, septiembre de 2013).

La situación - que no es novedosa en la lógica del sistema judicial- se vuelve relevante cuando el procedimiento desdeña versiones sobre el pasado que ponen en tensión el campo de la memoria con el campo judicial, recordando que la memoria no solo desconfía de la historia (Sarlo, 2006, p. 9; Jelin, 2002, p. 64), sino también de ese relato jurídico donde el derecho al recuerdo y a la subjetividad están constreñidos (Pollak, 2006, pp. 62-63).

Esa tensión se presenta en una audiencia de Justicia y Paz contra el bloque Calima, cuando el fiscal 18 describe de manera pormenorizada cómo se produjo la incursión de los paramilitares en abril de 2001, destacando el número aproximado de hombres que iniciaron la incursión; fecha y lugar de salida; sitios que alcanzó el recorrido; personas asesinadas, desaparecidas y desplazadas; breve descripción forense de las personas asesinadas, entre los datos más relevantes. En uno de los recesos, los asistentes y representantes de las comunidades discutieron la presentación del fiscal señalando lugares y personas asesinadas y desaparecidas que no habían sido mencionadas en la descripción. Los líderes esperaron que en la sesión de la tarde se hiciera mención del asunto, pero ello no ocurrió. La inquietud fue percibida por el representante de la Procuraduría General de la Nación que, culminada la jornada, se sentó con los aborígenes y los campesinos para explicarles que la fiscalía no se había equivocado, que estaba demostrado cuál había sido el recorrido seguido por los paramilitares. Posteriormente, nos sentamos a conversar con el funcionario, quien cuestionó las versiones ofrecidas por los pobladores respecto a sitios, fechas y acciones que fácticamente no están relacionados con la incursión de abril de 2001. El argumento central del operador judicial, compartido por los otros funcionarios, es que esas versiones hay que desestimarlas porque

compañero/a permanente o parientes. En el ámbito jurídico colombiano se trata de un derecho consagrado en el artículo 33 de la Constitución Política, y en el artículo 68 del Código de Procedimiento Penal (Ley 906 de 2004). 
no corresponden a la "realidad", de cierta forma son "falsas", en un horizonte donde los fiscales se vanaglorian de haber efectuado una reconstrucción "fiel” de la incursión a la región del Naya ${ }^{81}$. Ahora bien, lo que los operadores judiciales no perciben es que los recuerdos que surgen en los testimonios no son "falsos" aunque no correspondan a una evidencia factual, y tampoco se cuestionan sobre el porqué del traslado tanto espacial como temporal de esas acciones, sitios y personas asesinadas, encuadradas ${ }^{82}$ en la incursión de abril de 2001.

El traslado, sobre todo temporal, ha sido una de las preocupaciones de Alessandro Portelli $(1989 ; 1993 ; 2002)$ en los estudios sobre memoria. Para el historiador italiano los relatos y testimonios que son catalogados como "equivocados" - pues no siempre son fiables para una rigurosa reconstrucción de un hecho-, tienen un valor extraordinario en cuanto que ellos reposan intereses y deseos de unos recuerdos que van más allá de la materialidad visible de un acontecimiento, lo que obliga al investigador a tratar de comprender los significados que subyacen en los relatos $(1989$, p. 6). Señala Portelli que en la acción de recordar es frecuente que haya una transposición cronológica, producto del funcionamiento de la memoria; es usual que al evocar un evento se registre una descomposición temporal que se da tanto en el plano horizontal a través de una periodización que individualiza el evento en bloques temporales homogéneos al estilo de un antes o un después, como en el plano vertical implicado en una actualidad que permite descomponer el tiempo en tres modalidades que involucran episodios

81 La reconstrucción jurídica fue hecha por la Fiscalía 18 de Justicia y Paz el viernes 15 de junio de 2012 ante una magistrada del Tribunal Superior de Bogotá, en la diligencia de imputación de cargos contra 66 postulados del bloque Calima.

82 La revisión de la literatura (Namer, 2004; Candau, 2006; Jelin, 2002; Ricœur, 2008) muestra un consenso respecto a las lecturas y las interpretaciones que adquiere la noción de Halbwachs de memoria colectiva, prefiriendo asumir la categoría de marco social, donde el individuo reconstruye su pasado en los marcos sociales presentes de un grupo. Una categoría similar a la de marco social es propuesta por Henri Rousso (1991) y retomada por Michael Pollak (2006), quienes hablan de encuadramiento de la memoria, memoria encuadrada o trabajo de encuadramiento para referirse a esa "memoria común" que provee puntos de referencia que otorgan cohesión. 
"ético-políticos", “colectivos" y "personales", que se mezclan y se sobreponen en la memoria:

Más tarde esas secuencias se vierten en la fragmentación horizontal del tiempo de modo individualizado y a pesar de que hayan transcurrido contemporáneamente a otras secuencias se pueden periodizar por acontecimientos que suceden en momentos diferentes... Fechar un acontecimiento significa no tan solo referirlo a una periodización horizontal sino también escoger en qué modalidad lo podremos colocar: el tiempo se convierte en una especie de entramado donde las modalidades y periodizaciones influyen los unos sobre los otros. (Portelli, 1989, p. 25)

Volviendo a las inquietudes de los pobladores respecto a la descripción oficial que estableció la fiscalía, las versiones que se ofrecen por algunos sobrevivientes (cargadas de un dramatismo que en principio delatan un recuerdo no superado) permiten vislumbrar unas "realidades" que no forman parte de la versión que se construyó en el escenario judicial. El tema aflora cuando conversamos con varios pobladores sobre la actual situación de la región, sus problemas y sus desafíos. En medio de la charla, una de las mujeres comienza a hablar sobre la situación de las viudas que dejó la masacre. Se trata de una líder de la comunidad de La Paz, cuyo esposo fue desaparecido por los paramilitares en una ronda de las que hacían en las noches por las veredas de la región. En medio de la charla, Rosa cuenta que las "cuarenta y pico de viudas en su mayoría no han sido reparadas e incluso algunas no han sido reconocidas como víctimas ante la ley" (notas de campo, octubre de 2013). Cuando escucho la cifra expreso mi sorpresa, pues si ellos sostienen que hay cuarenta y pico de viudas, pero la fiscalía habla solo de 19 personas asesinadas, varias de ellas mujeres, las cifras simplemente no concuerdan. A partir del cuestionamiento, los que participan de la charla comienzan a ofrecer sus versiones:

Es que ese es el problema, no están reconociendo a varias mujeres a las que les mataron el esposo cuando los paramilitares llegaron a la zona.

¿En la incursión de abril de 2001? 
No, hablo desde que llegaron a comienzos del año 2000, cuando los paramilitares empiezan a meterse a la región y comienzan a matar gente. Incluso, las viudas del año 2000 son más numerosas que las de abril de 2001.

Al principio, no nos damos cuenta que eran ellos [los paramilitares] porque a la región subía mucho comerciante a vender cachivaches, así como mucho joven a trabajar la tierra como raspachín ${ }^{83}$. Nos empezamos a dar cuenta porque luego los veíamos parados en el puesto militar de Timba o porque volvían a subir pero ya vestidos de militares, señalando y ejecutando gente.

¿Ahí comienzan los asesinatos?

Claro, empiezan las ejecuciones, sobre todo en horas de la noche. Ellos iban recorriendo las veredas buscando dizque a la gente que auxiliaba a la guerrilla, pero en esas cayó gente que no tenía nada que ver.

El río se convierte en cementerio, porque ellos cogían a la gente y la torturaban, la picaban con motosierra y los pedazos los tiraban a las aguas del [río] Naya. Muchas viudas son viudas sin que existan cuerpos...

A mi esposo lo agarraron una noche del mes de octubre, yo estaba en la casa cuando sentí unos disparos y tuve un mal presentimiento y me puse a rezar. Luego, sentí una camioneta que pasó y me asomé a la puerta... Luego vino un amigo y me dijo: "Cogieron a su marido"... Esa misma noche, lo busqué, pero nadie me dio razón de él. Al día siguiente me fui hasta Timba y pregunté por él directamente a los paramilitares, pero me dijeron: "Mira, india,

83 Expresión empleada en Colombia para referirse a las personas (en su mayoría campesinos) que en las zonas rurales se dedican a deshojar el arbusto o planta de coca. Se calcula que por cada arroba recolectada se paga alrededor de seis mil pesos, es decir, unos dos dólares. De acuerdo con los pobladores de la región del Naya, un raspachín puede obtener ganancias de alrededor de 80 mil pesos semanas, alrededor de 25 dólares, lo cual resulta más rentable que dedicarse a cultivar cualquier otro producto. 
no busques más que a tu marido lo matamos"... A él lo descuartizaron y lo tiraron al río, no hay cuerpo.

El golpe más duro fue en nuestras veredas La Paz, Río Mina, El Placer, El Saltillo. Cuando la gente no era arrojada al río, los cuerpos aparecían por los caminos, uno o dos personas por día... Pero esa situación no es visible, porque lo visible fue lo que ocurrió en abril de 2001 por la cantidad de paramilitares que ingresó al mismo tiempo. (Notas de campo, octubre de 2013)

De acuerdo con la reconstrucción de la fiscalía, los sitios recorridos durante la incursión de abril de 2001 fueron los siguientes: Timba, El Porvenir, El Ceral, La Silvia, Palo Solo, Río Mina, El Placer. Ante el acoso de la guerrilla, un grupo de paramilitares se aleja del curso del río Naya y luego se desvía hacia San Antonio, departamento del Valle del Cauca, donde asesinan a 14 personas cuyos cuerpos aún no han sido exhumados por la fiscalía. El otro grupo permanece en Puerto Merizalde, donde son capturados por la infantería de marina.

Nos dicen que esas muertes no son masacre, porque masacre es cuando matan a cuatro, cinco o más al mismo tiempo, pero como los muertos eran uno o dos por día, pues el registro fue como asesinato. (Anónimo, notas de campo, octubre de 2013)

La conversación continúa con relatos que aluden a las atrocidades perpetradas por los integrantes del bloque Calima, de modo que la reconstrucción y la representación no está dada sobre relatos que se pudiesen catalogar de equivocados, pues buena parte de las acciones descritas están soportadas en denuncias penales, legitimados, además, por los informes institucionales de la Defensoría del Pueblo que, desde finales del año 2000, comenzó a alertar sobre la presencia de los paramilitares en la región del Naya, advirtiendo la inminencia de una incursión de mayor envergadura. Ello no implica que no se registre una transposición cronológica que sigue ubicando las acciones en abril de 2001, de manera que la traslación también puede operar en aquellos que escuchamos los relatos con fechas prefiguradas por el despliegue mediático posterior que tuvo la masacre. Sobre la base de relatos y versiones que no son equivocados, repito, hay en el 
plano horizontal una descomposición cronológica que ubica dos episodios que marcan lo que los relatos definen como sus "dramas". El primer evento es el secuestro en la iglesia La María (ciudad de Cali), ocurrido el 30 de mayo de 1999 cuando un comando del Ejército de Liberación Nacional se llevó a más de cien personas pertenecientes en su mayoría a la élite de la ciudad. La liberación total de las personas secuestradas se extendió hasta el mes diciembre de ese año. El problema es que las personas secuestradas fueron llevadas por los insurgentes a la zona montañosa de la cordillera Occidental donde se ubica la región del Alto Naya. Según los relatos, a partir de ese momento, las comunidades son estigmatizadas como auxiliadoras de la guerrilla:

El secuestro de La María, ese fue el comienzo de nuestra tragedia, fue un grave error del ELN traer a esa gente a la región porque fuimos señalados de auxiliadores, pero cauxiliadores de qué o de quién?

En una ocasión, tuve que ir hasta Cali para averiguar sobre un subsidio... me atendió un muchacha que se me quedó viendo cuando dije que era víctima de la masacre, luego me dijo: "Ahora sí son víctimas, pero cuando auxiliaron a la guerrilla que tenía secuestrada a la gente de La María, ahí si no eran víctimas”[...].

Esta región es muy grande, entre una vereda y otra perfectamente puede haber tres o más horas de distancia. Si usted le pregunta a la gente de muchas veredas de arriba, ellos no sabían de los secuestrados de La María, pero, así se supiera, ¿qué podíamos hacer? La gente no entiende que las comunidades no somos auxiliadores de nadie, somos víctimas de los insurgentes.

[...] lo de la gente de La María fue uno de los tantos conflictos que tuvimos con el ELN. Es muy fácil señalar, pero los que nos juzgan no recuerdan que uno de nuestros líderes, el gobernador Elías Tróchez ${ }^{84}$, fue asesinado por el ELN precisamente por denunciar

84 Elías Tróchez Quiguanas fue gobernador del Alto Naya en tres oportunidades (1996, 1999 y 2000). Su asesinato, perpetrado por el ELN el 12 de diciembre 
sus atropellos contra las comunidades. Yo misma me salvé de una ejecución a orillas del río Naya poco después de que mataron a nuestro gobernador...

No sé si sea cierto, yo creo que sí, pero la masacre del Naya fue un desquite por lo de La María. La llegada de los paramilitares fue poco después de que los secuestrados fueron liberados. Por eso nosotros insistimos en que se sepa quién ordenó la masacre... Ese es uno de los pedazos que aún falta... (Anónimo, notas de campo, octubre de 2013)

El otro episodio, que es un momento crucial para algunas personas que sobrevivieron a las acciones del bloque Calima, está en la acción paramilitar de abril de 2001. En este evento, se entrelazan esas modalidades temporales que incluyen lo político, lo colectivo y lo personal.

Los muertos y desaparecidos empiezan en el año 2000, pero como cada día aparecía uno o dos en distintos lugares, pues el asunto, a pesar de lo grave, no despertó las alarmas...

Los paras hacían rondas todos los días desde mediados del año 2000, y al que iban cogiendo lo iban matando sin mayores preguntas, para ellos todos somos auxiliadores de la guerrilla. También comenzaron a controlar todo, pues ellos montaron un puesto en Timba. Dejaban comercializar algunos productos, otros los prohibieron. Cobraban vacuna por ciertos productos, pues ellos sabían que arriba había cultivos de coca. También amenazaban a la gente para que no anduviera con cierta cantidad de plata (dinero). Los que no hacían caso o así lo hicieran eran "picados" y tirados a las aguas del río, y para mí eso es más grave que lo que ocurrió en abril de 2001 porque de esos muertos no se habla...

Aunque los paras andaban jodiendo desde el 2000, matando gente, intimidando a las comunidades, nadie se imaginó que ellos

del año 2000, se produjo cuando el grupo insurgente declaró objetivo militar a cinco comuneros de la región, entre ellos el gobernador. En esa época, también se registra la presencia del bloque Calima. Para tratar de mitigar la situación, el gobernador conformó una comisión para informar a las autoridades 
fueran a reunir a una fuerza tan grande para ingresar de esa forma a la región del Naya. Todos decíamos "esos qué van a subir por esas lomas” [...].

Llegué a Santander de Quilichao una semana antes de la incursión y me quedé donde una amiga. Cuando le dije que me iba para la región (Alto Naya) me advirtió que se rumoraba que los paras iban a subir, pero que era un ejército completo... Yo no le creí, hasta me reí porque no me imaginé que ellos de verdad fueran a subir con toda esa gente. Y subieron... (Anónimo, notas de campo, octubre de 2013)

Los dos últimos testimonios resultan reveladores porque indican la incredulidad de los pobladores de una posible acción paramilitar en la región del Naya. Los relatos expresan que los paramilitares, desde el año 2000, estaban presentes en la región, al punto que tenían un puesto militar montado en la población de Timba, un lugar estratégico porque es la puerta de entrada a la región del Alto Naya. En ninguno de los testimonios recabados entre los sobrevivientes se logra establecer una explicación al porqué de la acción paramilitar, por lo cual las explicaciones solo pueden ser ofrecidas por los perpetradores.

En la audiencia del 15 de junio de 2012, el fiscal 18 de Justicia y Paz narró ante una magistrada del Tribunal Superior de Bogotá cómo se planeó la incursión del mes de abril de 2001 a la región del Naya, a partir de los testimonios de Elkin Casarrubia Posada, alias El Cura, segundo al mando del bloque Calima; Juan Mauricio Aristizabal, alias El Fino; y Armando Lugo, alias El Cabezón. De acuerdo con sus testimonios, el objetivo de la acción fue controlar militarmente una región geoeconómicamente estratégica porque la cuenca del río Naya es un corredor natural que conecta la cordillera Occidental con la costa Pacífica, lo cual facilita la salida de cocaína. El control militar debía

departamentales y nacionales de la situación que se estaba viviendo en la región del Naya; pero es asesinado por el ELN bajo la acusación de querer colaborar con el grupo paramilitar. Los registros y los testimonios expresan que entre noviembre de 2000 y enero de 2001, el ELN fue altamente agresivo con la población del Naya (Jaramillo, 2011, p. 34). 
apuntar a crear un bloque en la costa Pacífica que "tuviera un corredor por los municipios costeros de Valle y Cauca, con asiento en el municipio de Guapi (Cauca)".

Con ese propósito, según los testimonios, el bloque Calima llegó a la región en mayo del año 2000 y estableció puntos de control militar que poco a poco fueron cercando literalmente las comunidades. Los paramilitares comenzaron a controlar el ingreso de productos a la región del Naya (por algunos de ellos cobraron lo que denominaron "impuesto"), prohibieron remesas mayores a cincuenta mil pesos y controlaron tanto el ingreso como la salida de la población a la región. Las versiones escuchadas a lo largo de la jornada coincidieron en señalar que el objetivo no fue perpetrar una masacre, lo cual coincide con los testimonios rendidos por Éver Veloza García, alias $\mathrm{HH}$, ante los tribunales de Justicia y Paz. Dice el principal comandante del bloque Calima:

Lo que yo pensaba cuando estaba en la guerra era que la mejor forma de matar al enemigo era metiéndosele a la casa del nido, y yo organicé un grupo para tratar de quitar ese corredor que tenía la guerrilla por el Naya, y tratar de montar un grupo entre [las poblaciones de] López de Micay y Guapi [Cauca] ${ }^{85}$.

Hay dos situaciones para analizar en las narraciones de los indígenas y los campesinos: aunque se da una transposición temporal en algunos relatos que ubican de manera deliberada una serie de acciones que ocurrieron durante el año 2000 en la incursión de abril de 2001, los testimonios hacen una lectura que construye un sentido global que sitúa la incursión de abril como el colofón de un gran evento que arranca desde el momento en que los hombres del bloque Calima comienzan a patrullar las veredas del Alto Naya, sin que ello implique trastocar esas dimensiones temporales horizontales que se acoplan con eventos que determinan un momento crucial. En otras palabras, los relatos

85 Esta misma versión fue ofrecida por el perpetrador a periodistas del portal digital Verdadabierta.com en mayo de 2009. El apartado que se cita forma parte de ese material periodístico (García, 2009). 
hacen la transposición en un movimiento estratégico que acepta que el evento reconocido social, mediática y periodísticamente es la incursión de abril de 2001, lo que permite observar las acciones que, según los sobrevivientes, no tendrían la misma relevancia; y esto implica que la transposición esté aparejada con la construcción de una narrativa que evoca lo ocurrido en el Alto Naya como una masacre que integra distintas acciones, siendo la más grave la masacre de abril de 2001. De ahí que en los testimonios se exprese el reconocimiento de ser víctima o sobreviviente de la masacre, indistintamente de si los hechos perpetrados acontecieron en los años 2000 o 2001. Ahora bien, la transposición problematiza la versión "oficial” (que incluye lo judicial, lo mediático-periodístico y el discurso de algunas organizaciones sociales y comunitarias) en torno a una masacre que limita la acción a lo sucedido en abril de 2001, y considera los eventos ocurridos a lo largo del año 2000 como acciones que, parafraseando a García Márquez, presagiaban la crónica de una muerte anunciada. Lo cierto es que el sentido elaborado por los sobrevivientes de la masacre del Naya para interpretar como un solo evento todas las acciones ejecutadas por el bloque Calima -en un horizonte temporal que abarca poco más de un año-, encuentra asidero al relacionar el asunto con las confesiones de los jefes paramilitares del bloque Calima en Justicia y Paz. En la primera versión colectiva que se hizo en abril de 2011, los perpetradores reconocieron la ejecución de varias masacres entre finales del año 2000 y comienzos del 2001. Incluso en algunas versiones también hay una transposición que elimina el tiempo transcurrido entre el arribo de los paramilitares a comienzos del 2000 y la incursión de abril de 2001. Por ejemplo, tanto en las declaraciones ofrecidas en las audiencias de Justicia y Paz como en las entrevistas concedidas para distintos periodistas, Éver Veloza García sostiene que la intención del bloque Calima en la región del Naya nunca fue la de perpetrar una masacre, pero el silencio impera cuando tiene que explicar las razones por las cuales se ejecutó la acción; el silencio se rompe para describir cómo se planeó y desarrolló la acción de abril de 2001.

Una situación similar ocurre con las declaraciones de Elkin Casarrubia Posada, quien, como segundo al mando en la jerarquía del bloque Calima, confirma la idea respecto a que el objetivo del bloque 
Calima no era perpetrar una masacre, y acota que el propósito era realizar un "recorrido". Pero la versión resulta poco verosímil si se tienen en cuenta, por un lado, las declaraciones ofrecidas por los perpetradores respecto a que el bloque Calima ya había propinado golpes significativos a la insurgencia con el propósito de ejercer control territorial en la región. Por otro lado, una revisión geográfica de la zona permite observar que si la tarea era ubicar un grupo entre las zonas de López de Micay y Guapi el acceso era mucho más sencillo por la costa desde el municipio de Buenaventura y no atravesar la región del Alto Naya, cuyas condiciones geográficas son intrincadas por ser un área montañosa (véase mapa). Cabe recordar que los propios comandantes confesaron que la masacre de Yurumanguí, planeada y ejecutada para distraer la atención de los militares que perseguían a los hombres del bloque Calima atascados en Puerto Merizalde porque desconocían la región, se orquestó en el municipio de Buenaventura. No obstante, los testimonios de los perpetradores insisten en que:

La incursión no tenía como objetivo cometer una masacre. Era llegar al Bajo Naya para pasar a López de Micay e instalar ahí un grupo. El objetivo era hacer un recorrido. Señores magistrados y víctimas, soy el más interesado en que estos hechos queden claros por respeto a todas las personas que murieron en esta barbarie y que claman justicia. Asumo la responsabilidad de todo lo que sucedió. (Declaración de Éver Veloza García, alias HH)

Lo cierto es que, indistintamente de si hay o no un lapsus temporal en las declaraciones de los paramilitares, el asunto es aclarado por la propia fiscalía a través de preguntas que buscaban fijar mojones espaciotemporales precisos: se entiende que el asunto es soslayado por unos operadores judiciales que terminan por editar las confesiones para organizar una versión coherente que registrara las acciones en un horizonte temporal en el que cada hecho tiene una fecha precisa. También se entiende que, para efectos de judicialización, es necesario para la fiscalía asumir cada acción victimizante del bloque Calima como un evento único; pero frente a esa narrativa judicial que fragmenta las actuaciones paramilitares, surgen recuerdos que hablan de 
más de cien personas asesinadas en la región del Naya en un ejercicio en el que tiempo y espacio se condensan. De ahí la sentencia de Elvira: "Nosotros pedimos verdad, justicia y reparación por todos los afectados en el Naya, por los que murieron en abril, incluyendo los arrojados por los peñascos, pero también por los que murieron antes" (notas de campo, octubre de 2013) ${ }^{86}$.

\section{La "verdad": una construcción social polisémica}

La justicia transicional, que implica transformaciones radicales en el orden social y político en escenarios que pasan de un régimen totalitario o dictatorial a uno democrático, que experimentan la finalización de conflictos internos armados y buscan la consolidación de la paz (Uprimny, Saffon, Botero y Esteban, 2006; Dodson y otros, 2010; Reed y Ciurlizza, 2009; Minow, Crocker, David y Mani, 2011; AndreasForer, 2012), tiene como uno de sus pilares centrales el reconocimiento y la garantía a los derechos de verdad, justicia, reparación y no repetición para las personas y las comunidades que sufrieron los estragos de acciones violatorias a los derechos humanos. En Colombia, los instrumentos normativos que introducen el marco transicional tienen el propósito de alcanzar la reconciliación y la paz después de más de seis décadas de confrontación armada ${ }^{87}$. No obstante, como lo señalan

86 La petición de la líder está justificada cuando el propio Éver Veloza García reconoce en una entrevista periodística concedida al programa Contravía (diciembre de 2008) que el número de personas asesinadas en los departamentos del Valle y Cauca pudieron ser más de 2000 entre los años 2000 y 2004, la mayoría sin la posibilidad de que sus cuerpos pudieran ser recuperados porque fueron arrojados a los ríos.

87 Los instrumentos son: la Ley de Justicia y Paz (Ley 975); Ley 1424 (2010), que modificó la Ley 975 de 2005 respecto a otorgar libertad y suspender penas para los desmovilizados que hayan manifestado su compromiso con la reintegración a la sociedad colombiana y no hayan cometido crímenes de lesa humanidad; Ley 1448 (2011) (Víctimas y restitución de tierras); y el Marco Legal para la Paz, aprobado en junio de 2012 (Acto Legislativo 01, 2012), que introduce a la Constitución Política artículos transitorios que otorgan facultades especiales al legislador para diseñar instrumentos de justicia transicional de carácter judicial o no judicial. El punto crucial del Marco Legal para 
algunas reflexiones (Díaz, 2010; Torregrosa, 2011; Aranguren, 2012; Reyes y Martínez, 2012), el marco transicional que se encara conduce a preguntar hasta qué punto se puede hablar de transición en una sociedad que no experimenta en su vida cotidiana precisamente esas transformaciones en el orden político y social. Como lo he mencionado en otros apartados, es lo que ocurre con los representes de la región del Naya que asisten a las audiencias de Justicia y Paz contra el bloque Calima de las Autodefensas. En los juicios, estos representantes comunitarios son alejados de las discusiones y debates en torno a la justicia transicional, por lo cual elaboran un profundo escepticismo de las bondades del proceso en el que son protagonistas de primer orden. A partir de los relatos de algunos representantes de las comunidades del Alto Naya, conviene mostrar esas experiencias enmarcadas en situaciones paradojales y contradictorias en relación con esos imperativos jurídicos de la justicia transicional, comenzando por la "verdad".

\section{Los juzgamientos}

De acuerdo con el artículo 29 de la Constitución (CP, 1991), el debido proceso es un principio jurídico para garantizar los derechos mínimos de una persona en el desarrollo de una causa procesal que asegure un resultado justo y equitativo. En la primera versión libre, rendida por los hombres del bloque Calima en marzo de 2011, los representantes de las comunidades de Alto Naya asistieron para escuchar las confesiones de los perpetradores. Tras agotadoras jornadas, la insatisfacción brota en el rostro de Elvira. Su desazón no es por lo que los perpetradores dicen o silencian; su malestar está relacionado con el proceso que se configura en las sesiones en las que el ritual jurídico se desenvuelve siguiendo unos protocolos ${ }^{88}$ en los que los perpetradores tienen

la Paz es la posibilidad que se otorga al legislativo para que ordene renunciar a la investigación penal de ciertos casos, para adoptar otros mecanismos no judiciales y colectivos que hagan posible el esclarecimiento de la verdad y la reparación de las víctimas.

88 Respecto al protocolo hay que identificar dos niveles. Primero, está la fase procesal que adelanta la Fiscalía ante magistrados de Justicia y Paz. Esa fase 
la oportunidad de ser escuchados, haciendo valer ante el juez lo que el tecnicismo jurídico denomina "legítimas pretensiones".

Los que perpetraron la masacre fueron procesados y condenados con penas ejemplares por la justicia penal colombiana, pero, según Elvira, tuvieron la oportunidad de defenderse, tuvieron la oportunidad de hablar y de justificarse... Ahora en el escenario de Justicia y Paz, 63 hombres del antiguo bloque Calima de las Autodefensas que fueron condenados por la perpetración de la denominada masacre del Alto Naya de 2001 esperan obtener una rebaja que prácticamente los pondría en libertad, pues la pena máxima que contempla la Ley 975 (2005) es de ocho años de prisión y ellos ya purgaron ese tiempo. Elvira comprende que esa rebaja que otorga la justicia transicional estará dada si los paramilitares dicen la "verdad" en sus confesiones, pero ello no implica que sus valoraciones pongan en cuestión lo que cataloga como una injusticia en caso de que los perpetradores obtengan la rebaja: "Las comunidades del Naya también recibimos una condena, mucho más dura que cualquier prisión: fuimos asesinados, desaparecidos, torturados, desplazados y humillados sin que pudiéramos defendernos. Esa es la verdad" (notas de campo, junio de 2012).

En el fondo, su discusión está relacionada con lo asimétricos que resultan los dos modelos de justicia que subyacen a su experiencia como sobreviviente de la guerra en el Cauca y líder que representa a su comunidad ante las instancias judiciales: 1) el juicio a que fue sometida despuntando el año 2000 por el Ejército de Liberación Nacional, obligándola a exiliarse del territorio. De igual forma, el juicio adelantando por el bloque Calima de las AUC en la incursión de abril de 2001,

implica: 1) la audiencia de versión libre, en la que los perpetradores acogidos a la ley confiesan los hechos victimizantes para garantizar la "verdad"; 2) la audiencia de formulación de la imputación de cargos, basada en las confesiones rendidas en las versiones libres y en las investigaciones adelantadas por la Fiscalía; 3) la audiencia de formulación de cargos; 4) la audiencia de control de legalidad; 5) la audiencia de incidente de reparación integral, y 6) la audiencia de sentencia. En un segundo nivel, cada una de estas etapas fija los procedimientos para garantizar la participación de los actores involucrados que, en el caso de las víctimas, siempre actúan a través de un tercero, bien sea la propia Fiscalía o, en caso de tener recursos económicos, un abogado. 
bajo la sindicación de ser auxiliar de la guerrilla; 2) el proceso contra los integrantes del bloque Calima en el marco de Justicia y Paz. Para ejemplificar el argumento y apelando a algunos testimonios ofrecidos, en la siguiente tabla, se sintetiza lo que para Elvira representaron los dos procesos judiciales a los que fue sometida por el grupo insurgente ELN y el bloque Calima: tabla 1.

El malestar de Elvira es simple y razonable: más allá de entender que el sistema judicial tiene que ofrecer las garantías procesales a unos confesos perpetradores, esa comprensión no aliviana la frustración existencial de saber que los pobladores del Naya también fueron sindicados, enjuiciados y condenados, en muchos casos a la pena capital, por unos actores que fungieron, al mismo tiempo, como fiscales, jueces y verdugos.

Este escenario de juzgamiento está relacionado con el antiguo sistema de pruebas legales en el que la indagación está acompañada por torturas y suplicios contra unos pobladores que de antemano son considerados como culpables. Siguiendo a Foucault (2000, p. 18), el cuerpo, entonces, es el objeto privilegiado para infligir el castigo; la venganza es la motivación de un poder que convierte el suplicio en espectáculo ejemplarizante. En el sistema legal de pruebas, el suplicio se define como una técnica que cumple tres criterios: por un lado, producir cierta cantidad de sufrimiento que retenga la vida en el dolor; por otro, el suplicio está calculado en aras del cumplimiento de ciertas reglas que fijan una correlación entre el tipo de perjuicio corporal y la gravedad del delito; finalmente, el suplicio debe ser resonante y exhibir públicamente la verdad del crimen, de forma que los excesos ponen de manifiesto una economía del poder (1985, pp. 39-41).

Ahora bien, el terror es la estrategia de dominación que determina las relaciones entre los paramilitares y los pobladores del Alto Naya ${ }^{89}$.

89 De acuerdo con el informe del Grupo de Memoria Histórica (GMH), adscrito al Centro de Memoria Histórica, la masacre como modalidad de violencia que produce terror responde a uno de los dos modos de anclaje entre los actores armados y las comunidades: anclaje originario o endógeno, donde se puede observar una presencia constante de grupos insurgentes que asumen funciones de regulación inestable, ligado a la presencia de grupos armados 
Las confesiones de los hombres del bloque Calima en las audiencias de Justicia y Paz coinciden en señalar que sí emplearon métodos para provocar "pánico", "miedo" y "terror” para destruir la capacidad de resistencia de las comunidades. Al respecto, Elkin Casarrubia Posada, alias El Cura, jefe militar y segundo al mando del bloque Calima, reconoció, en junio de 2012, que hubo "excesos" contra las comunidades, respondiendo a directrices impartidas por Carlos Castaño, quien, según Casarrubia Posada, consideraba que las Autodefensas debían provocar el "máximo temor" al ingresar por primera vez a una zona. Como en otros episodios protagonizados por los paramilitares, la tortura, el suplicio, la sevicia y la muerte atroz son la principal forma de lenguaje. En el Naya, ese mismo lenguaje de terror también caracteriza las relaciones que se establecen con los grupos insurgentes, pero en unas prácticas que, a diferencia de los paramilitares, permiten cierta resistencia en cuanto que los grupos están asentados en la zona. En otras palabras, el hecho de que los grupos insurgentes habiten en la zona obliga a establecer reglas dentro de las cuales la muerte es un recurso límite en las relaciones y el terror como forma de dominación se expresa en otras prácticas como la amenaza, el asesinato selectivo y las desapariciones forzadas, especialmente ${ }^{90}$. Distinta es la relación con los paramilitares, que difunden el terror a través de prácticas de muerte en una degradación límite de la condición humana. En ese sentido, es problemático escuchar los testimonios de Éver Veloza García, alias $H H$, pues, en sus relatos, se percibe una especie de naturalización de las prácticas de matar a alguien, justificada por las lógicas de la guerra. En el caso del Naya, por ejemplo, Veloza García rechaza la

para controlar territorios en los que comienzan a despuntar ciertas dinámicas económicas, incluyendo los cultivos de hoja de coca. El caso del Alto Naya responde al primer tipo de anclaje, sin desconocer que en la región también predominan los cultivos ilícitos. Según el informe del GMH, la estrategia de los grupos paramilitares en zonas de anclaje endógeno implicó un repertorio de violencia de tierra arrasada o exterminio, combinada con alianzas estratégicas para tratar de mantener un control duradero (2013, p. 39).

90 Así también lo consigna el informe general del GMH, teniendo como base los informes de los casos estudiados por el СMH (2013, p. 50). 


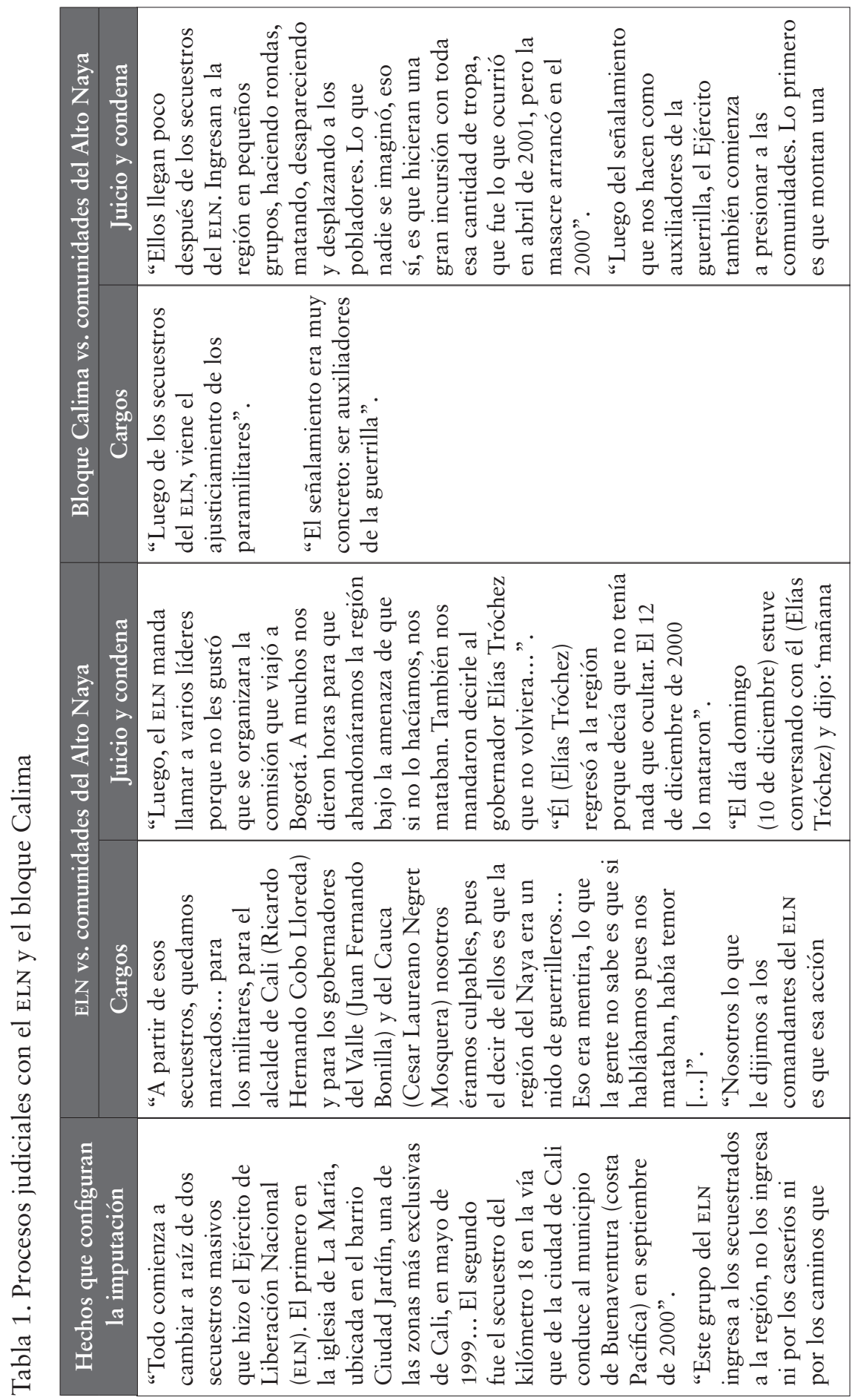




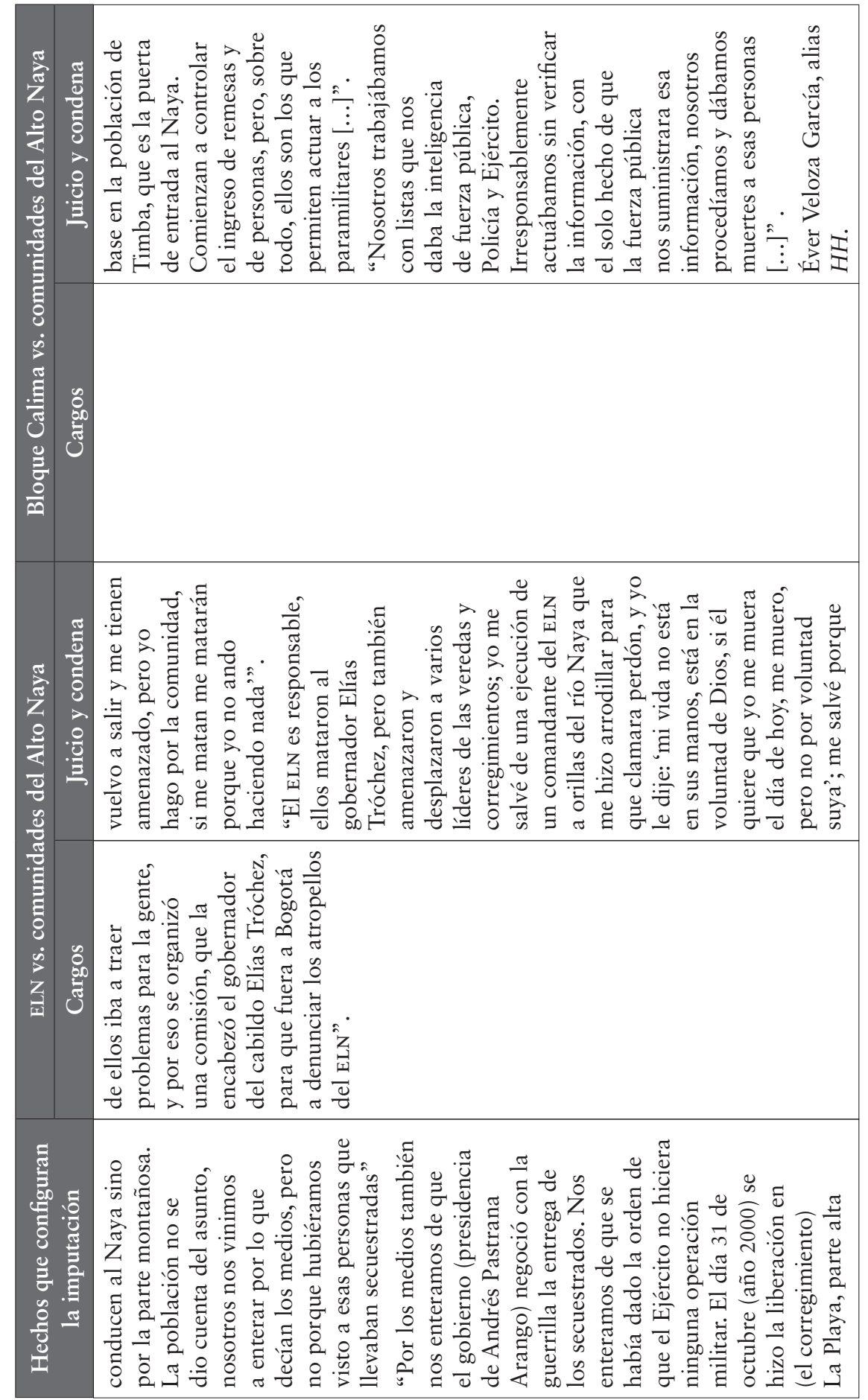




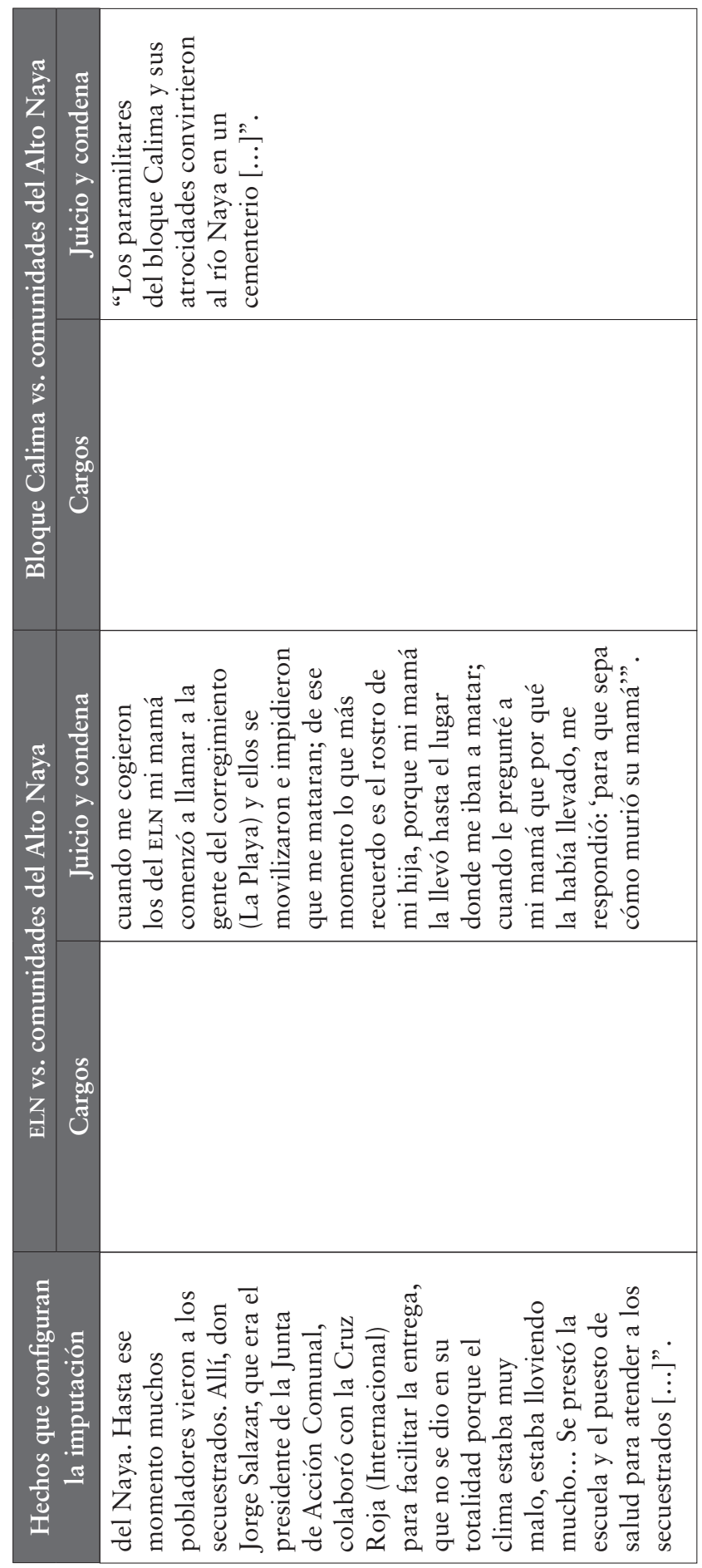


acusación en torno a cuerpos descuartizados y arrojados a los abismos, pero acepta que en la incursión de abril degollaron a varias personas, entre ellas a dos niños, dizque para que "no hicieran bulla y alertaran a la guerrilla". De igual forma, reconoce que se "mocharon las manos a una sola mujer, pero no se descuartizó a ninguna persona" (mayo de 2009).

No obstante, Elvira estuvo presente en el episodio al que hace referencia Veloza García. Recuerda que a la mujer a quien le "mocharon las manos" era una joven (18 años, según el examen pericial de la Fiscalía) que se llamaba Gladys Ipia. Los paramilitares la acusaron de guerrillera porque venía vestida con sudadera y botas de caucho:

Cuando subimos a El Ceral me bajaron de la chiva... Tipo seis de la tarde bajó una niña que venía del Naya, y se la dedicaron a ella porque traía una sudadera verde y unas botas y estaba toda embarrada. La empezaron a atormentar porque la chuzaban con unas agujas y decían: “¡Perra! Decí que vos sos guerrillera”. Y la niña les decía: “¿Cómo le voy a decir eso si yo no soy guerrillera?”. En esas, llegó el comandante y le dijo: "Pero mira la pinta en la que vienes, es pura pinta de guerrillera". En ese momento intervine y dije: "Todo el mundo que sale del Naya, sea hombre o mujer, tiene que andar así porque por esas trochas no hay de otro modo". Uno de ellos me dijo: “¿Tú la conoces?”, le dije que sí la distinguía y me respondió: "No te preocupes por ella, preocúpate por tu vida, porque esa está en nuestras manos". A mí me dio rabia y le dije: "Mi vida no está en sus manos, usted me puede matar hoy, puede matarla a ella, puede matarnos a todos, pero usted no sabe cuál será su suerte". Esa persona yo no la he visto en las audiencias, y me parece que es al que llaman con el alias de Bocanegra, que nunca se entregó y no se sabe dónde está... Ya entrada la noche, comenzó la tortura psicológica, me pusieron a ver todo lo que le hacían a la niña, me dijeron que no comenzaban conmigo dizque porque yo no les lloraba, mientras la niña sí, yo no sé de dónde sacaba valor, pero en ese momento no me daba miedo... cuando la niña comienza a llorar y a suplicar que no la maten, ellos se ensañaban peor, les daba gusto ver cómo la gente suplicaba... 
Luego de la muerte de la niña, siguieron conmigo y el comandante me dijo: "Vamos a jugar contigo, pero de un modo diferente". Yo pensé que me iban a violar, pero lo que hizo fue meter un solo tiro en el arma y me dijo: "Vamos a disparar este revólver tres veces, y en esas te mueres o te salvas". De inmediato me pusieron el arma en la cabeza y dije: "Hasta aquí fue", dispararon pero no pasó nada, respiraba profundo y recuerdo que decía: "Dios mío, lo que tú quieras". Luego vino otro, porque lo más terrible es que ellos se peleaban por matar a la gente, como gatos peleándose por un pedazo de queso... ese cogió el revólver y disparó pero tampoco pasó nada... Eso es muy duro, el tiempo es eterno... Llegó otro y me miró a los ojos y me dijo: "Despídete". En ese momento me volví a envalentonar y le dije: "Pues dispare y máteme porque ya estoy mamada [cansada] de que me atormenten”. Disparó y no pasó nada. El comandante cogió el revólver y dijo: "India, tres personas intentamos matarte y no pudimos, no sé si ese Dios que tú profesas te salvó o este fierro no sirve para nada”, y agarró el arma y la estrelló contra una piedra. Me dieron cinco minutos para salir corriendo... (Notas de campo, junio de 2012)

El suplicio, que culmina con la muerte, se enmarca en un ceremonial en el que el cuerpo exhibe la verdad del crimen cometido, siendo al mismo tiempo la prueba fehaciente de la condena impuesta y ejecutada. El paramilitar, en calidad de verdugo, es ese adversario que ejerce la fuerza de un acto que conserva en su ritualidad el reto (Foucault, 1985, pp. 41-57). El comandante paramilitar exime a Elvira de la muerte porque ella logra superar la prueba impuesta (sortear el famoso juego de la ruleta rusa), aunque en el fondo la siguiera considerando culpable. Las palabras de Elvira tuvieron efecto no por los argumentos esgrimidos sino por el arrojo que demostró al encarar la situación. Su actitud frente a la muerte logró que su verdugo la tratara con respeto y no la sometiera a ningún suplicio, pero también se ganó el derecho a enfrentar una prueba que en ningún momento demostró su culpabilidad o su inocencia... demostró su valor.

Ahora bien, como una expresión de poder, el suplicio también expresa un ritual político en el que la infracción lesiona el derecho de 
quienes exhortan la ley, siendo el castigo una manera de administrar venganza (Foucault, 1985, p. 53) En los testimonios de los pobladores, no se cuestiona la idea de una vendetta producto de dos secuestros masivos perpetrados por el ELN, y que involucró a las comunidades cuando los insurgentes decidieron esconder a los secuestrados en la zona montañosa de la región. Esa "verdad", incuestionable para muchos habitantes en el Naya, se densifica con las confesiones de los comandantes del bloque Calima porque sus versiones revelan una estrategia (social, política y militar) mucho más compleja, en la que subyace la figura de un "tercero" que orquestó acciones militares en las que la masacre del Naya tan solo fue un episodio. ¿Quiénes fueron esos "terceros" que estuvieron detrás de las acciones del bloque Calima en los departamentos del Valle y del Cauca? Desde las primeras declaraciones ofrecidas a Justicia y Paz por Éver Veloza García (septiembre de 2007) se conoció el modus operandi del bloque Calima en los municipios que comprenden el sur del departamento del Valle y el norte del departamento del Cauca. Sostuvo Veloza García en sus confesiones judiciales que su llegada a la región se produjo a mediados del año 2000, cuando fue enviado directamente por Carlos Castaño, máximo jefe de las Autodefensas Unidas de Colombia, como hombre de confianza para reestructurar el bloque Calima. Las declaraciones señalan que el Calima era un grupo para esa época dividido en dos facciones, una de ellas estaba al servicio del narcotraficante Diego León Montoya Sánchez, alias Don Diego, uno de los principales hombre del cartel del norte del Valle. El trabajo de Veloza García consistió en reagrupar el bloque y reorganizar su estructura militar para iniciar una ofensiva contrainsurgente que incluyó acciones directas contra los frentes del ELN y las Farc-EP asentados en la región, así como acciones contra la población civil ${ }^{91}$, considerada como auxiliadora de la insurgencia. Por su parte, las fiscalías 18 y 40 de Justicia y Paz han logrado

91 Así lo corrobora la sala de Justicia y Paz del Tribunal Superior de Bogotá que en octubre de 2012 dictamina en el texto de legalización de cargos contra Veloza García: “A juicio de la Sala, el bloque Calima implementó unos patrones victimizantes sobre comunidades indígenas y negras de El Naya, contra líderes sociales, sindicalistas, educadores y menores". 
establecer, a través de los testimonios de los desmovilizados del bloque Calima, 1905 personas asesinadas en acciones que se extienden desde mayo del año 2000 hasta diciembre de 2004 cuando el grupo se desmovilizó ${ }^{92}$. Sin embargo, aunque las confesiones en torno a asesinatos, desapariciones, desplazamientos, entre otras violaciones a los derechos humanos, resultan importantes para ir construyendo esa "verdad" jurídica, y comprender la incidencia del bloque Calima en esa amplia región del suroccidente colombiano, también resultan trascendentes las confesiones de los antiguos comandantes del bloque que, en consonancia con los rangos que ocuparon en la jerarquía militar, vinculan en sus declaraciones a militares, dirigentes y empresas que colaboraron para que el grupo en un año largo tuviera el control del cincuenta por ciento de los municipios que integran el departamento del Cauca. Nuevamente, las declaraciones de Veloza García resultan las más dicientes puesto que fue el principal comandante del bloque. Las declaraciones de $\mathrm{HH}$ - tanto en Justicia y Paz como en el juicio que la Corte Suprema de Justicia de Colombia adelantó contra el político Juan Carlos Martínez por los vínculos con grupos paramilitares- sostuvo que el bloque Calima recibió apoyo de varias personas del ingenio azucarero San Carlos: Ramiro Rengifo, que se desempeñó como jefe de

92 Aunque las fiscalías logran documentar 1905 asesinatos, los mismos desmovilizados hablan de que la cifra es muy superior -Éver Veloza García habla de alrededor de unas dos mil personas entre asesinadas y desaparecidas - puesto que muchos cuerpos fueron arrojados a los ríos de la región, especialmente el río Cauca. Entre las acciones militares con mayor resonancia mediático-periodística están: masacre en el municipio de San Rafael, departamento del Valle, diciembre de 1999; dos masacres en el corregimiento de Sabaletas, municipio de Buenaventura, departamento del Valle, ambas en mayo de 2000; masacre en el corregimiento de San Antonio, municipio de Jamundí, departamento del Valle, diciembre de 2000; masacre en el municipio de Suárez, departamento del Cauca, diciembre de 2000; dos masacres en el municipio de Santander de Quilichao, departamento del Cauca, diciembre de 2000 y enero de 2001; masacre de La Rejoya, municipio de Cajibío, departamento del Cauca, enero de 2001. De igual modo, las confesiones de los desmovilizados del bloque Calima hablan de acciones militares aisladas en un horizonte temporal de cuatro años que cobijaron los departamentos de Valle, Cauca y Huila, donde fueron asesinados entre una o dos personas en cada acción. 
seguridad y proporcionó varias listas de personas, sobre todo sindicalistas, que posteriormente fueron asesinados; la dirigente María Clara Naranjo, gerente del ingenio en 2001; Bernardo Tezna Barrero, gerente entre 2003 y 2004; Andrés Orozco, director de sistema del ingenio. Las declaraciones también afirman que el bloque recibió para la época apoyo económico por un valor de veinte millones mensuales, sin que se precisara por cuánto tiempo se mantuvo la ayuda ${ }^{93}$. De igual modo, los desmovilizados coincidieron en señalar a varios dirigentes políticos que apoyaron económica y políticamente al bloque, entre quienes se destacan Manuel Mosquera, dirigente conservador; Carlos Castro, ganadero y expresidente de la Plaza de Toros de Cali; Fernando Prada, periodista de la ciudad de Cali; Luis Hernando Guerrero Santacruz, alcalde del municipio de Mercaderes (Valle del Cauca); Juan Carlos Martínez, entonces senador de la República; Juan José Chaux, gobernador para la época del departamento del Cauca. Las declaraciones de los paramilitares también han sido dicientes respecto a los apoyos que el bloque Calima recibió de integrantes de las fuerzas militares en el caso concreto de la masacre del Naya. Las confesiones de Elkin Casarrubia Posada, Armando Lugo y Éver Veloza García, especialmente, expresan que esa colaboración permitió que para la incursión

93 La versión ha sido corroborada por otros desmovilizados. Por ejemplo, en diligencia de versión libre fechada el 18 de diciembre de 2008, el desmovilizado Yesid Enrique Pacheco Sarmiento, alias El Cabo, mencionó las siguientes personas y empresas que financiaron el bloque: "empresas lideradas por Edgar Lennis, Hernán Gómez y Carlos Spa; el Ingenio San Carlos con un aporte de veinte millones de pesos mensuales; Incopesca, Bahía Cupica de Javier Armitanche, Manaba o Playa Nueva de propiedad de Fernando González, Timelco, Carnes y Carnes de propiedad de Julio Aristizábal, Galería Pueblo Nuevo, Juancho Transporte, JCM, Gustavo Calle, Milton Mejía, Restaurante Los Balcones, Víctor Olarte en Tuluá, Juan Bautista García Monsalve, Néstor Fabio Álvarez Pereira, Alfonso Luis Cruz, Félix Ocoro —exalcalde de Buenaventura-, Funeraria San Martín, Graciela Sánchez, Héctor Mondragón Jiménez, Piedad Vélez Rengifo, Carlos Alberto Rentería Mantilla, Granero JB, García y Hermanos Ltda., Manuel Mosquera, Fernando Prado, Carlos Castro, Bernardo Besna, Andrés Orozco, Cooperativa de Ganaderos del Centro del Norte del Valle del Cauca y para 2002, el Alcalde de López de Micay colaboraba con un aporte de un millón de pesos mensuales". 
del mes de abril —que movilizó a más de doscientos hombres— no hubiese ningún tipo de control para que los paramilitares se pudiesen trasladar desde distintas zonas del Valle y del Cauca para concentrase en un solo punto, pasando por, al menos, tres retenes militares, uno de ellos ubicado en la población de Timba. Armando Lugo, conocido con el alias de El Cabezón, sostuvo en audiencia celebrada el 29 de julio de 2010 que consiguió material de guerra (150 camuflados, 150 chalecos y 100 equipos de campaña) a través de Claudia Jaimes, esposa de un cabo del Ejército adscrito al batallón Pichincha de la ciudad de Cali. De igual forma, ratificó lo dicho por Veloza García respecto al apoyo recibido del capitán (r) Mauricio Zambrano Castro, el teniente coronel (r) Tony Alberto Vargas Petecua, comandante para la época del batallón de infantería n. ${ }^{\circ}$ 8, y del general (r) Francisco René Pedraza ${ }^{94}$, para la época comandante de la Tercera Brigada del Ejército ${ }^{95}$.

94 Una líder de la región del Naya recuerda que el general Pedraza llegó a los pocos días a Santander de Quilichao en momentos en que la Cruz Roja Internacional y las autoridades judiciales estaban recuperando algunos cuerpos de los asesinados en la acción de abril de 2001, que estaban dispuestos en un amplio salón. Relata la líder que al arribo del militar, acompañado por varios medios de comunicación, los soldados comenzaron a poner etiquetas a los cadáveres de los campesinos y los indígenas: "En ese momento, dije: 'Haga el favor de quitar esos letreros porque ellos no son guerrilleros'. Al señor no le gustó mucho, pero ordenó a los soldados quitar los letreros, quizá porque ahí estaban las cámaras de televisión y no quería escándalos" (notas de campo, septiembre de 2013).

95 Las declaraciones de los desmovilizados fueron la base para que en 2009 la unidad de Justicia y Paz de la Fiscalía compulsara copias con otras instancias del ente investigador para que se determinara la veracidad de lo confesado. La situación jurídica de algunos de los mencionados es la siguiente: dos indagaciones preliminares en 2010 contra el periodista Mario Fernando Prado y contra el empresario del Valle, Luis Fernando Castro Botero, que nunca trascendieron judicialmente; el juzgado penal especializado de la ciudad de Cali condenó el 31 de enero de 2012 a Ramiro Rengifo Rodríguez a 340 meses de prisión por los cargos de homicidio agravado y concierto para delinquir por el asesinato del sindicalista Jesús Orlando Crespo Cárdenas, ocurrido en enero del año 2000; Luis Hernando Guerrero Santacruz fue condenado en marzo de 2010 a 72 meses de prisión por el juzgado primero especializado de la ciudad de Popayán por el cargo de concierto para delinquir con paramilitares; 
La intervención de insurgentes, narcotraficantes, paramilitares, políticos, comerciantes, empresarios y militares en una serie de acciones violentas que marcaron el devenir de una región entre los años 2000 y 2004, permite inferir, por un lado, la disputa por mantener y extender unos poderes en el ámbito regional y local en áreas, especialmente rurales, donde la injerencia del Estado es frágil, aunque con una fuerte presencia de la fuerza pública. Por otro lado, las alianzas estratégicas entre algunos de los actores mencionados, que ubicaron como "enemigo" común a los grupos insurgentes como principal excusa para actuar sobre una región sobre la que se despliegan intereses económicos. Sobre esa compleja realidad, hay dos aspectos sobre los que quiero ahondar.

Dado que el procedimiento judicial implica individualizar los casos, cuando la Fiscalía encara la etapa investigativa y procesal, no resulta incorrecto efectuar una lectura particular de cada uno de los eventos perpetrados por el bloque Calima en la región del Valle y del Cauca; lectura que, por esa misma lógica, tiene la licencia de evitar cualquier tipo de relación o conexión entre un evento y otro ${ }^{96}$. En ese orden de ideas, tampoco resultaría incorrecto efectuar una lectura que, a partir de las declaraciones de los desmovilizados, interprete los asesinatos, las desapariciones, los desplazamientos forzados y las masacres

Juan Carlos Martínez fue condenado en junio de 2011 a 90 meses de prisión por la Corte Suprema de Justicia por el cargo de concierto para delinquir con paramilitares y narcotraficantes; Juan José Chaux es investigado por la Corte Suprema de Justicia por cargos relacionados con vínculos con paramilitares; los militares Mauricio Zambrano Castro, Tony Alberto Vargas y Francisco José Pedraza siguen siendo investigados por la Fiscalía, acotando que Vargas Petecua fue sancionado disciplinariamente por la Procuraduría en febrero de 2006 por el cargo de omisión para "perseguir y combatir a los integrantes de las Autodefensas Unidas de Colombia que llevaron a cabo una masacre de campesinos en la región del Alto Naya".

96 Un giro significativo al respecto es dado por la sala de Justicia y Paz del Tribunal Superior de Bogotá que, en el texto de control de legalidad contra Éver Veloza García, fechado el 31 de octubre de 2012, hace una lectura del contexto político, social y económico que enmarcan las acciones delictivas imputadas al entonces comandante de los bloques Calima y Bananeros de las AUc. Esa lectura permitió que, por primera vez en la historia judicial del país, se encontrara que lo acontecido con el asesinato sistemático de los integrantes de la Unión Patriótica (UP) fuera catalogado como un genocidio político. 
perpetradas por los paramilitares a lo largo de cuatro años como una estrategia política y económica que, utilizando al terror, se apoderó de la región a sangre y fuego ${ }^{97}$. En otras palabras, 1905 personas asesinadas, según la Fiscalía, más de dos mil desaparecidos, según Veloza García, y aproximadamente la ejecución de setenta masacres no son datos que expresen acciones aisladas. En esa estrategia política y económica, subyacen intereses de los diversos actores, que establecieron alianzas de distinta índole con los paramilitares en un juego de poderes que ubicaron a la insurgencia como "enemigo" común, en una región en la que se desarrollan grandes proyectos económicos, especialmente relacionados con la explotación minera ${ }^{98}$. Según lo declarado por los paramilitares del bloque Calima y las investigaciones judiciales, las alianzas respondieron a acuerdos particulares que Veloza García directamente fue realizando con cada uno de los actores, en una dinámica en la que se distinguen dos momentos: el primero es cuando dirigentes

97 La idea planteada se relaciona con la tesis de catalogar el fenómeno paramilitar colombiano como un proyecto que literalmente quiso refundar a Colombia (Valencia, 2008, p. 46). Lo que me parece importante es comprender las maneras en que el proyecto se ajusta a las dinámicas, intereses y características de cada una de las regiones que se quieren dominar militar y políticamente. En la región del sur del Valle y del norte del Cauca, el proyecto implicó alianzas con varios actores, entre narcotraficantes, terratenientes, empresarios, dirigentes políticos y militares.

98 En la región que comprende los departamentos del Valle del Cauca y el Cauca, se combinan en la actualidad dos estrategias económicas que son asumidas por las comunidades indígenas, afrodescendientes y campesinas como amenazas a la autonomía territorial y a la seguridad alimentaria. Por un lado, está el desarrollo de proyectos agroindustriales ligados a la producción y explotación del monocultivo de la caña, destinada a la producción de biocombustibles, que se extiende en más del $70 \%$ de la tierra fértil de la región del Valle; por otro, el desarrollo de proyectos de explotación minera, especialmente en el departamento del Cauca. Las dos estrategias están acompasadas con la creación de zonas francas que, entre otros aspectos, ofrece beneficios tributarios a más de cien empresas transnacionales que se instalaron en la región. En el momento, hay más de 1200 solicitudes de títulos de explotación minera que, eventualmente, cubrirían cerca de un millón seiscientas mil hectáreas (el 56\% del territorio). Entre las transnacionales mineras a las que ya se les concedieron títulos de explotación se encuentran Anglo Gold Ashanti, Cerromatoso y Carboandes. 
políticos, empresarios y comerciantes piden a la casa Castaño ayuda para que un bloque ingrese a la región a combatir la insurgencia, asumiendo el compromiso de financiar al grupo; cumplido ese propósito, que implicó el control territorial por los paramilitares, un segundo momento estuvo en la alianza que el bloque Calima estableció con narcotraficantes del Cartel del Norte del Valle, para pactar el pago de un impuesto sobre el tráfico de estupefacientes (cincuenta dólares cobró el paramilitarismo por cada kilogramo de cocaína que salió del puerto de Buenaventura) $)^{99}$. Sobre esa base, la Corte Suprema de Justicia determinó en su sentencia contra el político Juan Carlos Martínez (cuya primera parte reconstruye las incidencias del bloque Calima, sobre todo en el departamento del Valle) que las alianzas establecidas no tuvieron como "propósito cardinal" trazar un "proyecto político regional" al considerar que los vínculos fueron incidentales. Para el alto tribunal, la principal relación que estableció el bloque Calima en la región fue con el narcotráfico.

Lo paradójico de la lectura política (no jurídica) de la sentencia, es que esta se trata de una de las figuras más emblemáticas y polémicas de la dirigencia regional, Juan Carlos Martínez, ejemplo del maridaje de intereses políticos, económicos y sociales de la clase política y del paramilitarismo, en un marco de relaciones en el que la política y el delito aúnan esfuerzos para consolidar proyectos con intereses comunes

99 En la sentencia contra el dirigente político Juan Carlos Martínez, fechada el 8 de junio de 2011, la Corte Suprema de Justicia, Sala de Casación Penal, presenta como material probatorio el testimonio de Veloza García respecto a las ayudas recibidas en el momento en que se conforma el bloque Calima. Señala el entonces comandante: "Cuando llegamos al Valle del Cauca, llegamos primero, el primer grupo llegó por medio de Diego Montoya [uno de los principales narcotraficantes del cartel del norte del Valle] y Rasguño [Luis Hernando Gómez Bustamante]... cuando yo llegué en el año 2000, con el apoyo de los financieros, de los empresarios, de los arroceros y harineros, perdón, harineros y azucareros del Valle. Esos empresarios, como hice mención en Justicia y Paz, a los pocos meses desaparecieron y dejaron de darnos el apoyo, ahí fue cuando nosotros comenzamos a financiarnos del narcotráfico en Buenaventura y en todo el Valle del Cauca, o sea que el apoyo de los empresarios fue en el inicio del bloque Calima cuando yo llegué allá y después ellos desaparecieron y ello consta en mis versiones de Justicia y Paz”. 
(Enzensberger, 1987, p. 13) Lo cierto es que las alianzas trazadas por el bloque Calima con varios actores respondieron a una estrategia política y económica que implicó en una primera fase el control militar de escenarios vitales en los ámbitos regional y local.

Abro un paréntesis para referir el sugerente estudio de Ernst Kantorowicz (2012), respecto a los dos cuerpos del rey, donde analiza las diversas formas en que la teología jurídica de la Edad Media construyó esa representación dual en torno a la figura del rey con un cuerpo natural y, por lo mismo, transitorio - que enferma, envejece y muere-, y otro un cuerpo político que busca extenderse inmutable en el tiempo a través de la continuidad como dispositivo que legitima la ficticia y artificiosa premisa de la perdurabilidad de los poderes que representan ciertas personas o instituciones (p. 291). En el caso que nos ocupa, el poder no recae en el cuerpo de una sola persona, sino que se personifica en una pequeña y privilegiada colectividad que históricamente ha manejado las riendas de la región en términos políticos y económicos y, por otro lado, grupos de narcotraficantes que desde hace tres décadas también imponen sus propias lógicas y dinámicas de poder que incluyen tener injerencia en todas las esferas sociales de la región, incluyendo la clase política, con relaciones en las que el poder se mezcla con el delito y la violencia (Enzensberger, 1987, p. 25).

En ese contexto, la forma de accionar del bloque Calima hay que entenderla como la extensión de ese cuerpo político que, ante la amenaza que aún representan los grupos insurgentes, buscó, literalmente, defenderse. Esto no niega que, mientras se consolida la presencia del grupo paramilitar en la región, el bloque Calima buscó desarrollar su propia propuesta política y económica, replicando la dinámica vivida en otras regiones por otros bloques de las Autodefensas (Guzmán, 2007, p. 175; Jaramillo, 2011, p. 33; Céspedes, 2011, p. 54 ${ }^{100}$.

100 En la sentencia contra Juan Carlos Martínez, la Corte Suprema de Justicia presenta la declaración del desmovilizado Teodosio Pabón Contreras, alias El Profe, que es presentado como ideólogo del bloque Calima: "La historia ha mostrado que la presencia de las Autodefensas en las distintas regiones del país se da en cuatro fases: la primera es muy lamentable, que es la del terror, época en la que se dieron las distintas masacres; la segunda se conoce como los homicidios 
Ahora bien, esa simbiosis entre poder y violencia en la que se despliega una política de terror ha sido reconocida poco a poco por los desmovilizados del paramilitarismo en las audiencias de Justicia y Paz, pero fue orquestada y apoyada por una dirigencia política-económica que suele quedar invisible cuando los ejercicios de memoria se efectúan a partir de eventos aislados que, por lo mismo, no logran concatenarse unos con otros. Son ejercicios que, además, también acentúan la memoria literal (Todorov, 2000) de la narración dolorosa que reconstruye el asesinato, la desaparición y la tortura sin que, en muchos casos, se puedan observar los factores estructurales que subyacen a los eventos.

Esa política de terror abreva en la noción de terror total que Hannah Arendt planteó en Eichmann en Jerusalén (2013) como instrumento de exterminio producto de una planeación que no deja nada al "ciego azar" (p. 156) ${ }^{101}$. Esto hace que el miedo y la violencia sean herramientas eficaces que se mezclan con prácticas colaboracionistas que, aunque no llegan al extremo de que las víctimas voluntariamente cooperen con su propia muerte - que es uno de los puntos centrales del análisis de Arendt respecto al genocidio judío en la política de la Solución Final- sí permite reconocer una serie de personas que en distintos niveles ofrecieron recursos y ayudas para que el bloque Calima

selectivos; la tercera es la de trabajo social que se hace en las zonas cuando se ha desplazado al grupo enemigo, en este caso las Farc-EP; y ya una última fase en la que se aspira a hacer la consolidación del pensamiento político, pero como movimiento político de la organización de autodefensas”. Cabe anotar que en los registros de Justicia y Paz de la Fiscalía, este desmovilizado aparece registrado en el bloque Centauros, que operó en la región de los llanos orientales.

101 En su estudio sobre el miedo como idea política, Corey Robin (2009) sostiene que este se puede rastrear en concepciones que conforman una historia vinculada a proyectos políticos en los que el miedo estuvo al servicio de una élite política y cultural (2009, pp. 60-61). El estudio de Robin se centra en cuatro autores (Hobbes, el Estado moderno; Montesquieu, la ideología del liberalismo; Tocqueville, la democracia igualitaria; Arendt, el totalitarismo) que comprendieron, cada uno en su respectiva época, que el miedo era el fundamento de una nueva moral y una nueva política. Para Hannah Arendt, esa moralidad política estuvo materializada en la idea de terror total encarnada en la Alemania nazi y en la Rusia estalinista. Recuerda Robin que Arendt abreva de la idea respecto al terror como producto de la violencia (Montesquieu), 
se consolidara en la región. A pesar de lo limitados que suelen resultar los testimonios de los desmovilizados para identificar la participación de los actores mencionados en sus confesiones, muchos de ellos, incluyendo narcotraficantes, fueron más colaboradores que gestores, aunque algunos fueron los que invitaron al bloque Calima para que hiciera presencia en la región, pues el objetivo era "limpiar" —eufemismo de matar- a la región de insurgentes y otros "males" —indigentes (también llamados en el lenguaje coloquial "desechables”), consumidores de drogas, prostitutas, ladrones y homosexuales-.

El problema aparece cuando ese objetivo es para otros actores parte de una política que trasciende la simple colaboración. ¿Cuál fue, por ejemplo, el papel de las fuerzas militares en la consolidación del bloque Calima en la región? Los testimonios de los desmovilizados parecen validar la tesis defendida con ahínco por el Estado y las instituciones militares respecto a que la posible participación de militares en la masacre del Alto Naya (digo posible en cuanto que las investigaciones judiciales están vigentes y opera el principio de presunción de inocencia) fue producto de acciones particulares que no forman parte

y a la idea de que una masa angustiada es el mejor molde para el despliegue de prácticas despóticas (Tocqueville) y aderezadas por una noción de ideología que, en un horizonte de doctrina fanática como fueron el nazismo y el comunismo, atrajo a hombres y mujeres solitarios que necesitaban de "una verdad tranquilizadora" (p. 63). Esta nueva moralidad política implica la imagen de un "mal radical" en la que todos se vuelven agentes activos de un terror total del que todos somos cómplices. Por esta vía, moralmente era imposible juzgar a los perpetradores del terror total (p. 63). Un cambio radical a esa concepción aparece en la reflexión de Arendt sobre el juicio de Adolf Eichmann en Jerusalén, donde describe a un funcionario arribista que cumplía de manera eficaz las tareas trazadas por una política de exterminio claramente definida y ejecutada. El terror total, entonces, deja de ser la base de esa moralidad política expresada en el mal radical, para ser el síntoma de un acto banal que, sin dejar de ser terrible, pierde su profundidad moral: "Cuando hablo de la banalidad del mal lo hago solamente a un nivel estrictamente objetivo, y me limito a señalar un fenómeno que, en el curso del juicio, resultó evidente. Eichmann no era un Yago ni era un Macbeth, y nada pudo estar más lejos de sus intenciones que 'resultar un villano', al decir de Ricardo III. Eichmann carecía de motivos, salvo aquellos demostrados por su extraordinaria diligencia en orden a su personal progreso" (Arendt, 2013, p. 417). 
de una política institucional. Para los asistentes a las audiencias de Justicia y Paz por las comunidades del Alto Naya, esa postura no permite la reconstrucción judicial de los hechos, y expresa uno de los grandes vacíos contenidos en las recientes leyes que buscan una transición política y social: la negativa de reconocer que en sesenta años de conflicto armado las fuerzas militares también han sido responsables de acciones violatorias de los derechos humanos ${ }^{102}$.

De igual forma, los asistentes a las audiencias son escépticos respecto a la capacidad de la justicia colombiana para que militares y ciertos civiles comprometidos con el bloque Calima sean investigados y judicializados. Ese escepticismo es más profundo con el desarrollo de las audiencias, y tensiona el escenario judicial con el derecho de las víctimas y los sobrevivientes de la masacre a recuerdos en los que no se duda de la responsabilidad de los militares y los dirigentes. Para Mark Osiel (2000) esa tensión suele ser irreconciliable, pues las preocupaciones de los involucrados en una causa judicial son distintas. Mientras la víctima busca justicia sin que el fallo atropelle sus legítimos recuerdos, el operador judicial busca conclusiones profesionalmente correctas, sin olvidar a los historiadores que, conscientes de que los fallos judiciales son otra forma de hacer historia, asumen las discusiones desde una perspectiva interpretativa que los aparta de los tecnicismos jurídicos. Para Osiel (2000), los procedimientos judiciales provocan distorsiones en la medida en que los fallos no permiten comprender los eventos que tratan, bien por una "estrechez excesiva"

102 Quizá sea este uno de los puntos más controversiales de las leyes relativas a los procesos de justicia transicional en Colombia, las cuales no solo atribuyen exclusivamente la responsabilidad del conflicto armado a los denominados grupos armados ilegales (Ley 782 de 2002), sino que, además, eximen de manera taxativa de cualesquiera responsabilidades a los agentes del Estado en el denominado conflicto armado interno (literal cuarto del artículo noveno y artículo décimo de la Ley 1448 de 2001) (Reyes y Martínez, 2012, p. 86). La negativa a reconocer que las fuerzas militares también son actores que han perpetrado crímenes en el marco del conflicto armado interno en Colombia también es cuestionada por el CMH en su informe general ;Basta ya! Colombia: memorias de guerra y dignidad (2013, p. 20). 
o por "tapujos judiciales" o bien por una "amplitud" también excesiva que desborda las competencias profesionales ${ }^{103}$ :

Una forma frecuente de distorsión combina lo peor de las anteriores: presenta una conclusión profesionalmente correcta, perfectamente adecuada para los fines legales tradicionales, como si fuera mucho más, es decir, como una historia oficial del conflicto en su totalidad. (Osiel, 2000, pp. 79-80)

Osiel no olvida que la sospecha es recíproca tanto para la historia como para la memoria (Shudson, 1995). En síntesis, la historiografía puede distorsionar el derecho al interpretar los datos, pero la memoria, que es un ejercicio selectivo, implica inevitablemente una distorsión.

103 Puede ser el caso de la sentencia de la Corte Suprema de Justicia contra Juan Carlos Martínez, que hace una lectura de carácter político con la pretensión de ser la historia oficial de lo acontecido en los departamentos del Valle y del Cauca con el bloque Calima (2011). 

Ascenso a Río Mina, región del Alto Naya

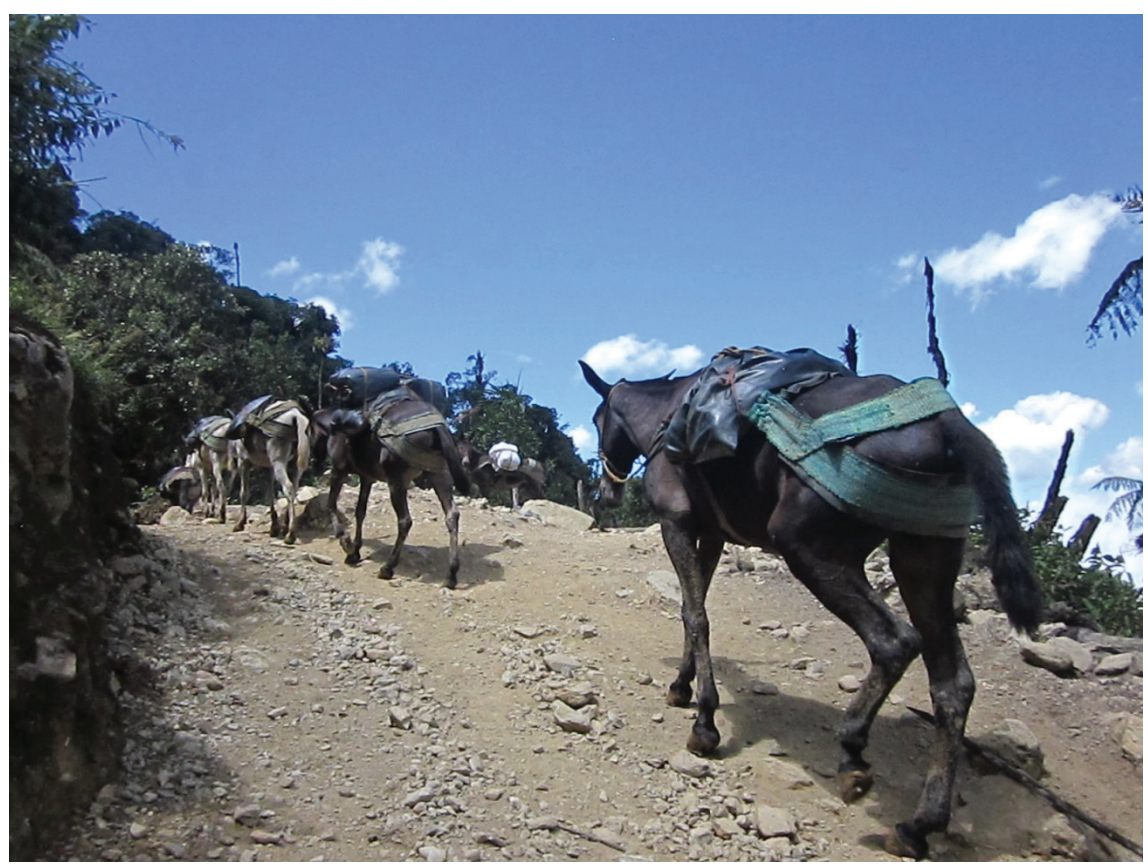

Fuente: Julio Enrique Cortés.

Nos dicen que esas muertes no son masacre, porque masacre es cuando matan a cuatro, cinco o más al mismo tiempo, pero como los muertos eran uno o dos por dia, pues el registro fue como asesinato...

Anónimo 